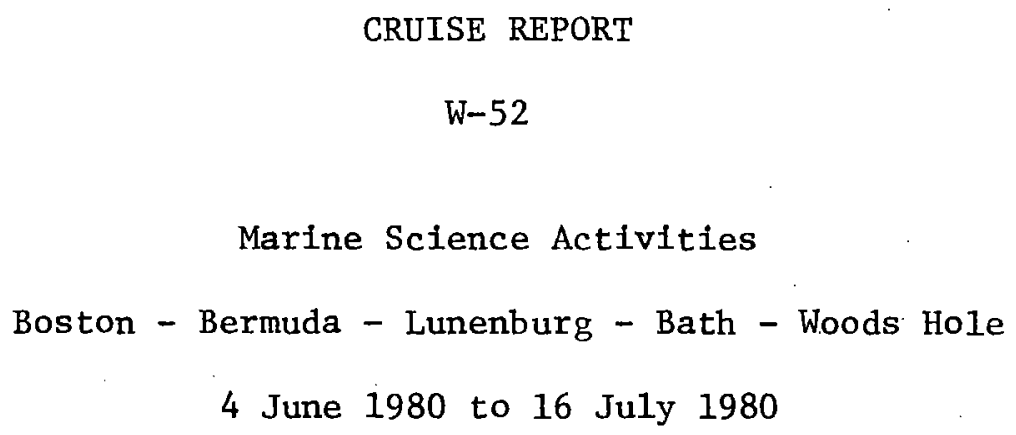




\title{
SARGASSO SEA
}

by Laura Fitch

\author{
Bluer than the sky \\ Where sunlight is transformed \\ Into diamonds \\ Upon each crest. \\ Swells expand and subside \\ Like the breath of the sea itself \\ Only horizon beyond the horizon \\ Is antictpation of Bermuda. \\ Momentarily, \\ We just roll along.
}




\section{PREFACE}

This document is a summary of the scientific activities carried out during $W-52$, the fifty-second cruise of $R / V$ Westward. It consists primarily of abstracts of student reports on their specific projects, but also includes an outline of other academic activities carried on during the cruise. The report is a shipboard document, written in transit from Lunenburg, Nova Scotia to Woods Hole, Massachusetts, the last leg of the voyage. It therefore represents data analysis such as is possible under the limitation of shipboard conditions. While student scientific work was planned ashore prior to the cruise, the realism of the sea and weather as well as shipboard restrictions of ten demanded considerable revision and in some cases new directions for projects. Reports and abstracts reflect these limitations as well as the considerable pressures of time the students experienced as their responsibilities became more demanding.

The vagaries of weather and the perversity of inanimate objects could only be dealt with successfully because of the outstanding contributions of the entire ship's staff. Rob Moir, in charge of scientific equipment, contributed his tremendous interest and enthusiasm for birds and mammals by outstanding lectures and constant leadership. Rindy Ostermann, assistant scientist, conveyed to the students by example and leadership that there was no job that couldn't be done, and infected all with her interest in the creatures of the deep.

The students of $\mathrm{W}-52$ enjoyed and benefitted from a great diversity of talents among the visiting scholars. Adam Joe, biologist, suffered the misfortune of combining the most susceptibility to seasickness with the worst weather of the entire cruise. Ron Eng, staff biologist for the Yale University Museum of Natural History, is the only person I have known that 
seemed to require no sleep whatsoever, having missed not a single overthe-side operation. Carol Reinisch, Ph.D., had the unique ability to draw parallels and connect scientific thoughts in what initially appeared to us as very disparate subjects, a tremendous learning experience for all of us, and she further proved to be a real "salt" in every way. Bill Fowler, Ph.D., provided the stimulus necessary to appreciate maritime history, particularly as regards the visits to the Bath Maritime Museum and the Bath Iron Works. Stuart Frank, M.A., delighted all of us with his considerable talents in things musical, and soon had us know the best shantles for hauling halliards and sheets.

A11 of us are indebted to the Captain, Rick Farre11, who not only guided the ship safely through what we felt was more than our share of gales, but also successfully handled the ship in what must be the only docking strictly under RADAR in the thickest Lunenburg fog ever experienced. His staff, the mates Paul DeOrsay, Chip Swicker, and Terry Hayward, combined the mastery of the traditional skill required of mates with good teaching and real understanding of students. Steve Miller, Engineer, and Mary O'Brien, Steward, were always on hand for the jobs rarely appreclated and yet vital for a smooth functioning ship.

Lastly I would like to express my appreciation to the most important persons of all -- the students. It is their interest and growth in skills, confidence and understanding that provides the satisfaction of this endeavor. When you have a group like $\mathrm{W}-52$, the cruise will be a success no matter what the weather may do.

Hermann Gucinski

Chief Scientist

W-52 
TABLE OF CONTENTS

PREFACE . . . . . . . . . . . . . . . . . . . . . . . . i TABLE OF CONTENTS

INTRODUCTION . . . . . . . . . . . . . . . . . . . . . . 1 ACADEMIC PROGRAM . . . . . . . . . . . . . . . . . . . . . . . 2 CRUISE NARRATIVE . . . . . . . . . . . . . . . . . . . 4 LONG-TERM INTERNAL PROGRAMS

Coasta1 and Pelagic Birds - R. Moir . . . . . . . . . . . 7 Marine Mammal Sightings - R. Moir . . . . . . . . . . . . . .11 Neuston Studies - A. Rand . . . . . . . . . . . . . . .13

a) Pelagic Tar Distribution

b) Halobates

COOPERATIVE PROGRAMS . . . . . . . . . . . . . . . . . . . . . 14

Weather Observation (NOAA)

Shark Tagging (NMFS)

SARGASSO SEA STUDIES

Introduction . . . . . . . . . . . . . . . . . . 15

Sargassum Weed Communities - H. Huddleston . . . . . . . . . 16

Primary Productivity in the the Sargasso Sea - P. Dunke1. . . . . . 17

Copepod Populations in Neuston Tows - M. Finch . . . . . . . . . . . 18

The feeding habits of Euphausilds in

the Sargasso Sea - R. Gorski . . . . . . . . . . . . . . . 19

Productivity Analysis Through Nutrient Measurement - P. Hansen . . . .23

The Relationship Between Diurnal Migration and

Pigments in Copepods - L. Carlson . . . . . . . . . . . . . 20

GULF STREAM RING STUDIES

Introduction . . . . . . . . . . . . . . . . . . . . . .21

Cold Core Dynamics - S. Gallagher . . . . . . . . . . . . . 26

Vertical Migration of Euphausids - L. George. . . . . . . . . . 25

The Effects of Cold Eddies on the Vertical

Migratory Behavior of the Lantern Fish - L. Herr . . . . . . . . 31

STUDIES ON GEORGES BANK AND ADJACENT WATERS

Introduction . . . . . . . . . . . . . . . . . . . . . .33

A Sedimentological Analysis of the Continental

Shelf of New England - A. Westinghouse. . . . . . . . . . 34 
The Relative Abundance of Benthic Foraminifera

in a Transect of the Continental Slope

Southeast of Cape Cod - M. Schulze . . . . . . . . . . . . . .37

Gonfaulax Off the Nova Scotian Coast - F. Schuh . . . . . . . . . . .39

Attracting Cod Using their Sense of Smell - C. Sohon. . . . . . . . . .40

The Analysis of the Stomach Contents of Fish - A. Knowlton . . . . . .41

Effects of Fish Age on Numbers of Parasitic Copepods - K. Tierney . . .42

Temperature and Salinity Differences and the

Ecto-Parasitic Burden of Gadus morhua - M. Dyer . . . . . . . . . . 44

The Immunologica1 Reactions of Gadus morhua to

the Infection of Porrocaecum decipiens - P. Berkner . . . . . . . . .46

STUDIES IN NAUTICAL SCIENCE

Introduction. . . . . . . . . . . . . . . . . . . .47

Forecasting Local Weather from Surface Observations - B. Linsley. • . 48

The Use of Underwater Lights for Swordfishing - K. McGrath . . . . . .50

Birds as an Ald to Navigation - G. Scott . . . . . . . . . . . .51

Hydro-Electric Generation Aboard Westward - A. Tomassetti . . . . . . .52

A Redesign of the Westward Galley - L. Fitch . . . . . . . . . . 55

SPECIAL COLLECTION - R. Eng . . . . . . . . . . . . . . . . 58

APPENDICES

A. Westward's Itinerary . . . . . . . . . . . . . . .59

B. Shtp's Complement . . . . . . . . . . . . . . . . 60

C. Demonstration Organisms: "Creature Features of '52" . . . . . .62

D. Lecture Topics in Marine Science . . . . . . . . . . . . . . .64

E. Summary Log of Stations . . . . . . . . . . . . . . .65

W52 Westward Song . . . . . . . . . . . . . . . . . . . . 67 


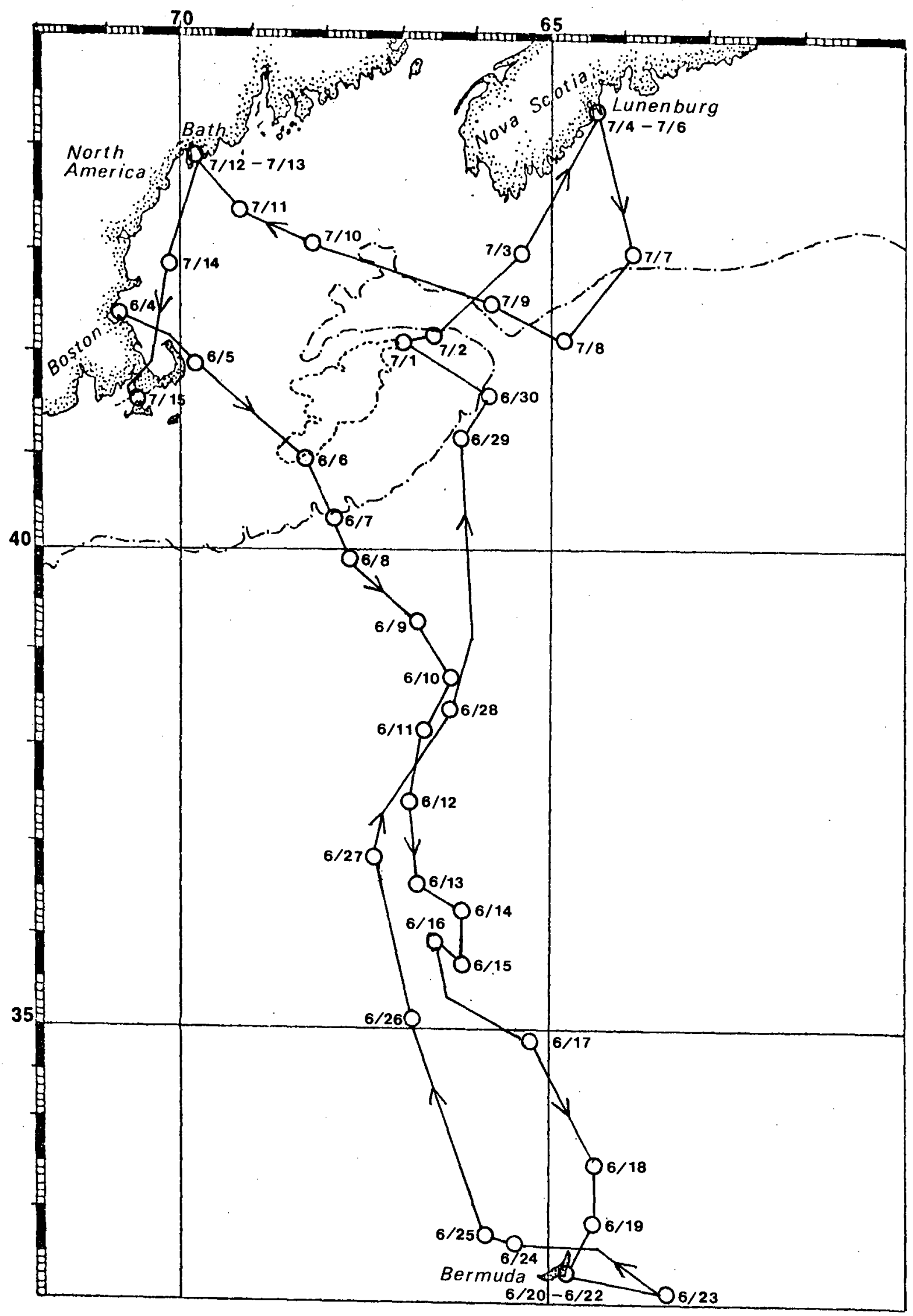

Figure 1. Track of Cruise $W-52$ of the $R / V$ Westward. 
The marine sclence objectives of cruise $W-52$ by $R / V$ Westward focused on three principal areas. These were a study of the physical, chemical, and blological characteristics of Gulf Stream rings, investigations of the plankton communities of the Sargasso Sea, and research relating to the fishes, plankton, benthos, and sediments of Georges Bank and the nearby continental slope. The ship's track is shown in Figure 1, and the ship's itinerary and complement are listed in appendices $A$ and $B$, respectively. The scientific activities were designed to expose the student to the entire spectrum of oceanographic sampling and analysis in the broadest sense. While the individual projects may appear highly focused, and in some areas reflect the methodology of a single discipline, all students participated in hydrographic stations, biological and geological observations, and some chemical analyses. Failures to achieve some specific objectives demonstrated that science at sea differs from science in textbooks; breakdown or loss of gear, optimistic assessment of the ship's sampling capabilities, reduced activity due to rough seas, and errors due to fatigue or inexperience provide object lessons that complement the successes. The former teach not only to develop a healthy skepticism toward highly polished reports, but also instill a sense of the tremendous self-discipline required to "keep on course" and meet the desired goals. The latter provide the satisfaction and insight that make science in general, and oceanography in particular, such rewarding endeavors.

As the projects reported here represent ongoing research, it is requested that reprinting or excerpts be made only by permission of the chief scientist. 
ACADEMIC PROGRAM

The Marine Science programs during Westward's cruise $W-52$ had three major components; these are, in order of importance:

1. Individual Research Project

Each student aboard Westward carried out a marine or nautical science project during the cruise that would demonstrate the principles of the sclentific method. The requirements were that

a. The project should take advantage of the opportunities offered

by Westward.

b. The project should be executed, analysed, and written in standard scientific format entirely aboard ship.

c. Planning and literature review, as well as a formal, written proposal, were required during the shore component of SEA's program. The projects covered a wide range of interests, and their abstracts constitute the bulk of this report. Additionally, oral presentations were required in seminar fashion, where discussion and critique were encouraged. The diversity demonstrates the versatility of marine sampling carried out aboard Westward.

\section{Science Watch}

A 24-hour science watch was maintained throughout the cruise, usually having three students assigned in addition to the science staff member. Watch duties included routine observations of oceanographic and metereologic variables, bird and mammal sightings, and maintenance of the ship's scientific log [kept on file at SEA], oceanographic sampling, data reduction and analysis, and individual project lab work. It is here that students get first hand instruction in sampling operations and benefitted from individual instruction and discussion.

The students' responsibilities were increased in a three-phase approach, culminating at a level where an individual would assume the direction of a sampling operation, as initially held by the staff scientist.

A collection of flora and fauna deemed typical or representative of the biological zones were sampled. This "feature creatures" collection provided stimulus for students to learn the use of keys, introduced toxonomic concepts and allowed familiarization with the ocean's diverse forms of life and their natural history. The specimen used are listed in appendix C. A "practicum" at the end of the cruise allowed evaluation of 
student progress in examination form.

\section{Lectures}

Forma1 lectures, given weekdays at sea, allowed group instruction where this proved the most efficient approach to promote rapid learning. Inttially toples were devoted to familiarlzation and instruction in methods. Later theoretical background germane to individual projects, sampling objectives, and oceanographic regimes were discussed, and finally the students themselves provided the forum. Appendix D 1ists the topics covered. 
CRUISE NARRATIVE

The R/V Westward departed Boston on June 4, 1980 and scientific operations commenced the following day, beginning with hourly sea surface and air temperature observations and semi-daily weather reports. A phytoplankton tow on Stellwagan Bank seryed as control for subsequent tows off the Nova Scotia coast near and at Northeast Channel. A transect consisting of bottom grabs and Phleger core samples was made across the southwestern portion of Little Georges Bank. Depths sampled started in 60 meters and ended on the continental slope in $1800 \mathrm{~m}$. of water.

Rough weather and hydrowinch problems delayed the first hydrowinch station until June 11. The station served as a slope water control for subsequent warm core eddy work just north of the Gulf Stream. Bathythermograph casts began on the 3 rd day and were made at frequent intervals unt11 the ship neared Georges Bank and the second leg of the voyage. BT's were used to detect and map both cold core and warm core rings, aided in location of Gulf Stream features, and provided comparative information on Sargasso Sea, Slope, and Shelf waters. BT observations were also used to determine temperature conditions for longlines set to catch swordfish. On June 9, and during the subsequent day, Westward's track allowed a transect of a warm core eddy, documented by extensive BT observations. Neuston tows were taken twice daily to chart the biota of the surface layers and to compare diel differences. Time constraints permitted only a single transect of the warm core ring, which commenced along an east-west line and was changed to a north-south track from the approximate center of the ring.

Investigations of the cold core eddy found at $50^{\circ} 40^{\prime} \mathrm{N}$ and $66^{\circ} 04^{\prime} \mathrm{W}$ were more intensive. Commencing on the morning of June 15 and continuing for over two days, work included two BT transects, a hydrocast near the center of the core, and zooplankton net tows at surface, 150, and 300 meter depths at 6 hour intervals over a twenty-four hour period.

Sargasso Sea studies after completion of cold core ring work were limited to midnight and noon neuston tows and to the routine weather observations mentioned earlier. Westward arrived in St. Georges, Bermuda on June 19th; scientific operations consisted of informal beach and inshore surveys as well as the collection of echinoderms, specifically sea-urchins 
and a few starfish, to be used for initial immunological work during the second leg of the voyage.

Departing in the afternoon of June 21, Westward ran into strong headwinds during the first night, proving for many that "sea-legs" can be lost even after only a few days ashore.

Midnight meter net tows were made for three consecutive nights beginning on June 23, with nets at depths of 10,150, and $300 \mathrm{~m}$. This essentially completed the sampling scheduled for the Sargasso Sea and hence no observations were deleted or lost when Westward ran into surprisingly high seas and 30 knot winds wh1le running north through the Gulf Stream. The first set of consistently fair winds encountered in this stage of the cruise were used to make a11 possible speed for Corsair Canyon at the continental shelf break just SE of the Winter Fishing Grounds of Georges Bank. Here the remaining meter net tows were scheduled for both daytime and nighttime.

In addition to the hydrostation taken to allow comparison of slope, Sargasso Sea, and Gulf Stream ring water, a longline was set in 100 fathoms of water at a location near the SE side of the canyon to maximize chances of swordfish catches. While the correct conditions were inferred from the literature, actual results were well below expectations - not a single fish was caught in the longline set on the night of June 29.

Westward moved right over the Winter Fishing Grounds of Georges Bank to attempt codfishing with jigs. This led to the only consistently successful fishing effort and provided the data base for the parasite, immunological and chemotaxis studies planned for in this area. An otter traw1 using a $15 \mathrm{~m}$ traw1 net brought back 5 haddock during the night of June 30 - July 1 . A slightly torn net demonstrated that the bottom was not suitable trawling ground despite the tempting scallops also brought aboard.

Operations on the Banks were concluded by the morning of July 2nd and the only sampling operations of biological nature done during the transit to and from Lunenburg (i.e. sampling within the Canadian fisheries protection zone) consisted of two phytoplankton tows taken to investigate the presence of dinoflagellates of the family Gonyaulax.

During the Lunenburg stop from July 4 through 6 , a science staff planning and review meeting was held on the LeHave River aboard the sloop "Minuette." The penultimate leg of the voyage, from Lunenburg to Bath, Malne, saw the final overboard sampling operations of the cruise. These 
consisted of phytoplankton tows only, when still within the Canadian fisheries protection zone, and a midnight zooplankton tow using three meter nets in the continental slope waters just offshore of the NE Channel between Georges Banks and the Scotian Shelf, as well as an unsuccessful Phleger core attempt.

A final effort at longline fishing was conducted on the 100 fathom curve at $43^{\circ} 06^{\prime} \mathrm{N}, 68^{\circ} 33^{\prime} \mathrm{W}$, the northern edge of Georges Bank. The only success was a small hake, a1though even the negative results provided some information on the use of lights to attract fish to longline balt.

On the remaining leg to Bath, Maine, as well as on the leg returning to Westward's home port of Woods Hole, Massachusetts, time was devoted to data reduction and analysis as well as report preparation, punctuated only by a whale watch maintained when transitting Jeffries Ledge and the vicinity of Stellwagen Bank.

Science operations, even if only in the form of report preparation and typing continued until Westward made fast at Dyer's Dock, Woods Hole at 0900 hours of July 16, 1980. 
LONG TERM INTERNAL PROGRAMS

Coastal and Pelaglc Birds

Rob Molr

W-52 allowed the opportunity to compare the avifauna of two very different water masses, continental shelf water and Sargasso Sea water. Bird counts were conducted during three consecutive ten minute observation periods. The highest counts per species per ten minutes were totalled for each observation station. This method is designed to minimize counting a bird as more than one bird should it be circling the area. It will also show changes in numbers over a short perlod of time. The count will be conservative, however, if birds are flying past the ship and out of sight.

Thirty-six bird observation stations were conducted during W-52. Fourteen stations were in shelf water where 418 birds were counted averaging 30 birds per observation. Eight stations were in slope water $\left(14-21^{\circ} \mathrm{C}\right)$ where 38 birds were counted averaging 4.8 birds per observation. In the Sargasso Sea, 22 birds were counted at 13 stations, an average of 1.7 birds per observation. These data are summarized in Table 1. Clearly, there are many more birds in shelf water than in either slope water or the Sargasso Sea. Even a low count of 1.7 birds per observation seems high for such a low nutrient and highly saline water mass. Seventy-five percent of the birds counted in the Sargasso Sea north of Bermuda were shearwaters, most of which were flying fast to the north, whereas most of the shearwaters counted in shelf water were accompanying or following the ship. It is likely that shearwaters were migrating through the Sargasso Sea to feed in the more productive shelf waters.

Eighteen bird species were observed during W-52 (see Table 2). Ten species were sighted in the Sargasso Sea. Fourteen were sighted in slope water. Table 3 shows incidental sightings of species not observed during observation periods. Three species landed aboard $R / V$ Westward (Table 3b). Appended is the complete record of observation stations. 


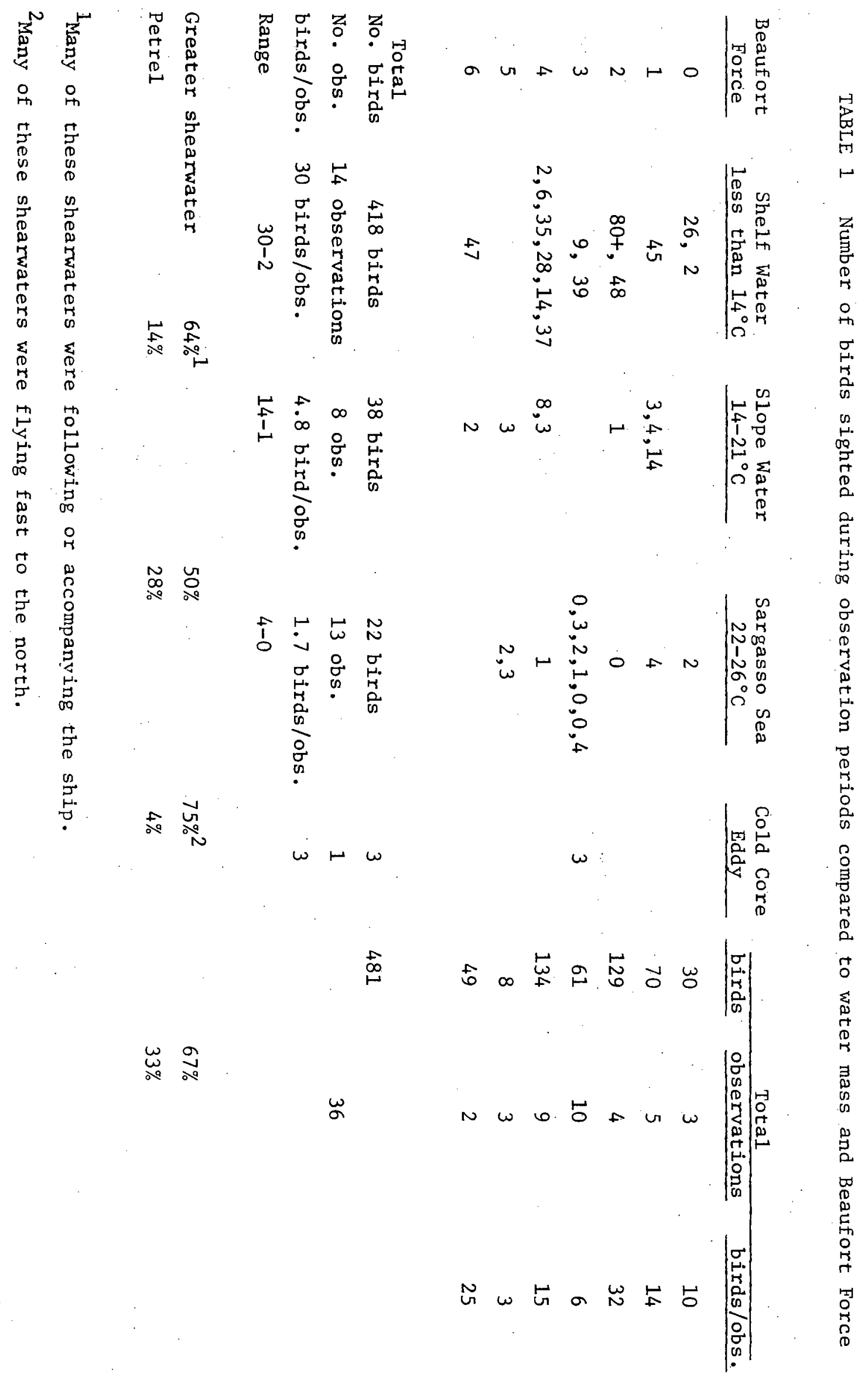


TABLE 2 Birds Sighted Offshore During $W-52$

Order Procellartformes

Fulmarus glactalis

Puffinus diomedea

Puffinus gravis

Puffinus 1herminerieri

Puffinus griseus

Pterodroma cahow

Oceanodroma leucorhoa

Oceanites oceanicus

Order Pelecaniformes

Phaethon 1epturus

Order Anseriformes

Anas rubripes

Order Charadrifformes

Stercorarius parasiticus

Larus marinus

Larus argentatus

Sterna paradisaea

Sterna hirundo

Thalasseus maximus

Order Passeriformes

Hirundo rustica Vermivora peregrina
'Tubenoses

fulmar

Cory's shearwater

greater shearwater

Audubon shearwater

sooty shearwater

Bermuda petre1

Leach's petre1

Wilson's petre1

white-tailed tropicbird

waterfow1

black duck

parasitic jaegar

great black-backed gull

herring gull

arctic tern

common tern

royal tern

perching birds

barn swallow

Tennessee warbler 
TABLE 3 Incidental sightings of bird species not observed during observation stations

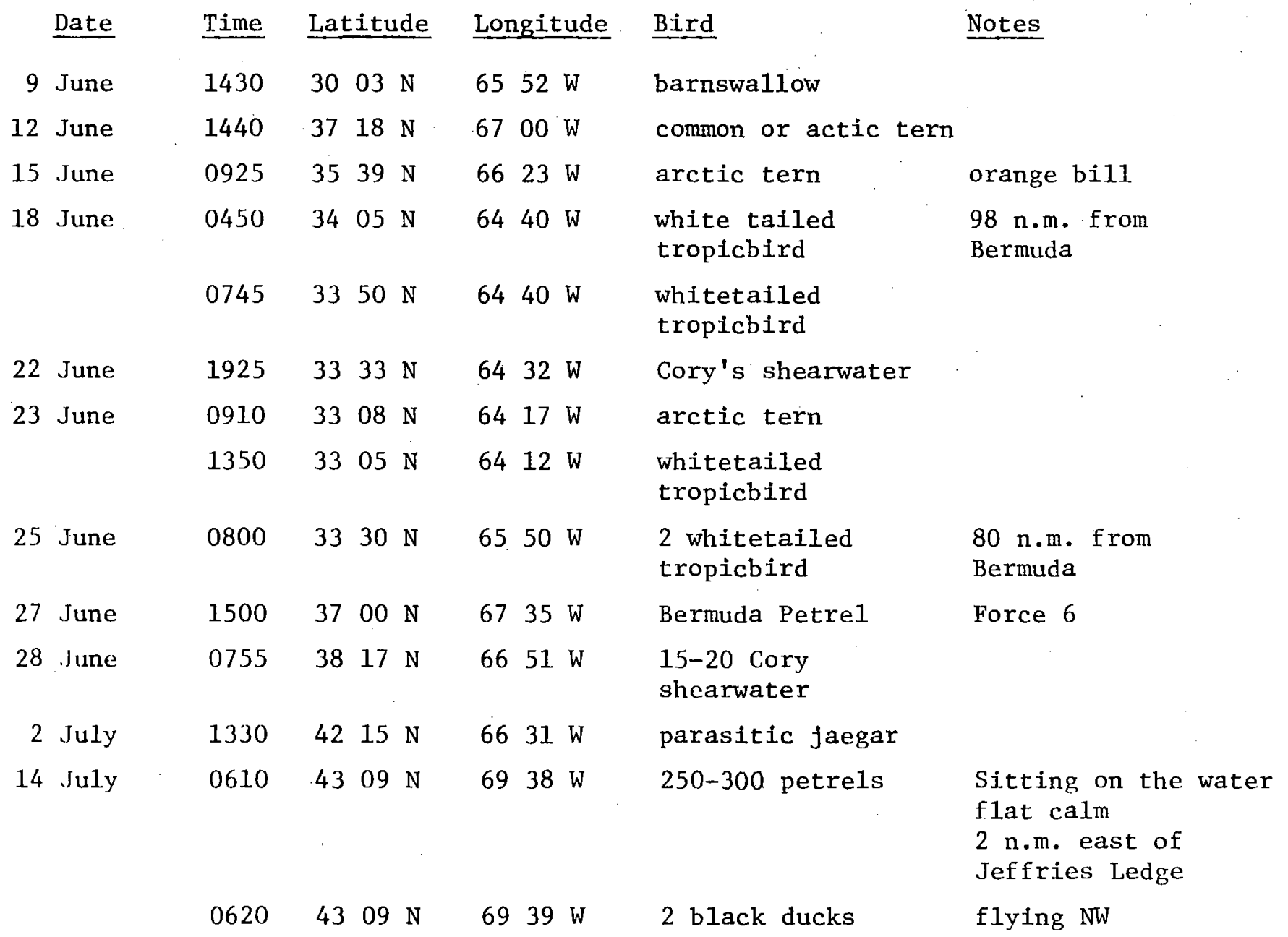

TABLE 3b. Birds that landed aboard $R / V$ Westward

$\begin{array}{rllllll}12 \text { June } & 0300 & 37 & 31 \mathrm{~N} & 6625 \mathrm{~W} & \text { Leach's petrel } & \text { wingspan } 21 . \mathrm{cm} . \\ 1 \text { July } & 1500 & 4201 \mathrm{~N} & 6659 \mathrm{~W} & \begin{array}{l}\text { Tennessee warbler } \\ \text { immature }\end{array} \\ 4 \mathrm{July} & 2050 & \text { Lunenburg Harbor, NS } & \text { Leach's petre1 } & \begin{array}{l}\text { found on board } \\ \text { at dusk }\end{array} \\ 8 \text { July } & 2130 & 4210 \mathrm{~N} & 6522 \mathrm{~W} & \text { Wilson's petre1 } & \begin{array}{l}18 \mathrm{~cm} \text {. span of one } \\ \text { wing } \\ \text { force } 4 \text { wind } \mathrm{S}\end{array}\end{array}$


Marine Mammal Sightings

Rob Moir

On this cruise all baleen whales were sighted in the vicinity of Stellwagen Bank and Jeffries Ledge with the exception of one humpback and one fin whale (see Table 4 for details). Sperm whales were a11 sighted near 900 fathoms of water on the continental slope. Pilot whales and dolphins were most frequently sighted in slope water, particularly near the Gulf Stream, with spotted dolphins more commonly found in warmer water and whitesided dolphins more commonly found inshore. Birds were frequently seen in the vicinity of inshore baleen whales and were very Infrequent with toothed whales (Table 5).

TABLE 4 Summary of Cetaceans sighted during W-52

\# wha1es \# sightings

Suborder MystIceti

Balaenoptera physalus Megaptera novaeangliae
Baleen Whale

fin whale humpback whale
9

10
7

6

\author{
Suborder Odontoceti \\ Physeter catodon \\ Globicephala melaena \\ dolphins spp. \\ Lagenorhyncus acutus \\ Stenella plagiodon \\ Delphinus delphi
}

Toothed Whale

sperm whale Atlantic pilot whale

white sided dolphin spotted dolphin saddleback dolphin

3

9

67-84

$16-19$

26-40

59-64
3

2

9

3 
TABLE 5 Breakdown of all Cetacean sighted during $W-52$

\begin{tabular}{|c|c|c|c|c|c|c|}
\hline & Date & Time & Lat. $(\mathrm{N})$ & Long. (W) & Cetacean & Notes \\
\hline \multirow[t]{5}{*}{5.} & June & 10510 & $42^{\circ} 08^{\prime} \mathrm{N}$ & $69^{\circ} 49^{\prime} \mathrm{W}$ & 2 finwhales & 20-30 gulls in vicinity \\
\hline & & 1215 & $41^{\circ} 49^{\prime} \mathrm{N}$ & $69^{\circ} 46^{\prime} \mathrm{W}$ & 3 humpbacks & 1 fulmar and petrel \\
\hline & & -1235 & $41^{\circ} 48^{\prime} \mathrm{N}$ & $69^{\circ} 46^{\prime} \mathrm{W}$ & 2 humpbacks & $\begin{array}{l}100 \text { herring gulls, } 6 \text { sooty } \\
\text { shearwaters, } 1 \text { greater } \\
\text { shearwater, } 1 \text { fulmar, } \\
12-16 \text { petrels }\end{array}$ \\
\hline & & 1400 & $41^{\circ} 40^{\prime} \mathrm{N}$ & $69^{\circ} 46^{\prime} \mathrm{W}$ & 1 finwhale & 1 sooty shearwater, I gull \\
\hline & & 2230 & $41^{\circ} 37^{\prime} \mathrm{N}$ & $68^{\circ} 57^{\prime} \mathrm{W}$ & $\begin{array}{l}4-6 \text { white sided } \\
\text { dolphins }\end{array}$ & bowriding, bioluminescence \\
\hline \multirow[t]{2}{*}{6} & June & 0110 & $41^{\circ} 36^{\prime} \mathrm{N}$ & $68^{\circ} 42^{\prime} \mathrm{W}$ & 8 dolphins & bowriding with bait fish \\
\hline & & -1300 & $40^{\circ} 48^{\prime} \mathrm{N}$ & $68^{\circ} 22^{\prime} W$ & 4 pilot whales & $\begin{array}{l}\text { greater \& sooty shearwaters } \\
\text { fulmar and petrels }\end{array}$ \\
\hline \multirow[t]{2}{*}{7} & June & 10255 & $40^{\circ} 36^{\prime} \mathrm{N}$ & $68^{\circ} 05^{\prime} \mathrm{W}$ & 2 dolphins & \\
\hline & & 1730 & $40^{\circ} 14^{\prime} \mathrm{N}$ & $67^{\circ} 51^{\prime} \mathrm{W}$ & 1 humpback & breaching, force 5 \\
\hline 8 & June & -0685 & $40^{\circ} 09^{\prime} \mathrm{N}$ & $67^{\circ} 48^{\prime} \mathrm{W}$ & $\begin{array}{l}\text { 12-15 sadd1eback } \\
\text { dolphins, } 6-8 \\
\text { smaller immature } \\
\text { dolphins }\end{array}$ & \\
\hline 11 & June & 1015 & $38^{\circ} 17^{\prime} \mathrm{N}$ & $66^{\circ} 44^{\prime} \mathrm{W}$ & $\begin{array}{l}\text { 13-20 spotted } \\
\text { dolphins, } 5+ \\
\text { juveniles }\end{array}$ & turtle spotted at 1040 \\
\hline 12 & June & 0700 & $37^{\circ} 38^{\prime} \mathrm{N}$ & $66^{\circ} 40^{\prime} \mathrm{W}$ & $\begin{array}{l}\text { 10-15 spotted } \\
\text { dolphins }\end{array}$ & bowriding \\
\hline 17 & June & 0700 & $-35^{\circ} 09^{\prime} \mathrm{N}$ & $65^{\circ} 16^{\prime} \mathrm{W}$ & $\begin{array}{l}20-30 \text { dolphins/ } \\
\text { porpoise }\end{array}$ & $\begin{array}{l}\text { sma1ler than spotteds, } \\
\text { rostrum less pointed but } \\
\text { not as blunt as a harbor } \\
\text { porpoise }\end{array}$ \\
\hline 18 & June & 0050 & $34^{\circ} 29^{\prime} \mathrm{N}$ & $64^{\circ} 38^{\prime} \mathrm{W}$ & 3 dolphins & bowriding \\
\hline
\end{tabular}


NEUSTON STUDIES

a) Pelagic Tar Distribution

Alice Rand

ABSTRACT

Pelagic tar lumps are believed to originate from crude oil lost during tanker washings. Many factors influence the distribution of tar, such as oceanic and atmospheric processes, tanker activity and the rate of deterioration. This project was aimed at determining if some areas were more concentrated with tar, and what factors influenced it.

Seventeen neuston tows between $39^{\circ} 21^{\prime} \mathrm{N}-66^{\circ} 39^{\prime} \mathrm{W}$ and $32^{\circ} 26^{\prime} \mathrm{N}-$ $64^{\circ} 14^{\prime} \mathrm{W}$ were collected. Samples of tar were weighed and found to range from $.5 \mathrm{gm}$. to $17 \mathrm{gm}$. ( $\pm .5 \mathrm{gm}$.) (mean $4.43 \mathrm{gm.}$ ). The samples also were measured and found to average between one and seventeen millimeters in size. The smallest quantity and size tar ball were found in the northern water and the largest in the cold core eddy within the Sargasso Sea.

Tar and Sargassum tended to both float together and the tar was also noted to adhere to the Sargassum weed. A possible reason for the largest quantity and size sample could be that it was half way between two shipping routes, which also was a cold core eddy.

The presence of tar lumps along Bermuda beaches was found both with and without Sargassum weed. The tar lumps were larger, possible accumulated particulates, and stickier. It appeared as if the island acts as a net and catches tar swept in by wind and currents.

The variation between Sargassum weed and tar provides the possibility of studying relatively independent colonies of Sargassum and ascertaining the ecological effects of the tar.

b) Halobates

Only two specimen of Halobates micans were collected during $\mathrm{W}-52$, allowing no generalizations concerning abundance. 
Cooperative Ship Weather Observation Program (NOAA)

Forty-one weather observations were prepared during the cruise. Observation times coincided with NOAA weather reporting requirements. Because considerable amount of time was spent in close proximity to land based stations, few transmissions were attempted. On1y when areas of 1ow weather reporting density were crossed did Westward transmit weather observations.

\section{Shark Tagging Program (NMFS)}

Fishing operations during W-52 were concentrated in the Georges Bank region and adjacent waters, with Iongline attempts at Corsair Canyon and on the southern edge of Northeast Channel in the Gulf of Maine. Jigging for cod was done on the Winter Fishing Grounds of the Banks. At no time were sharks attracted or caught, hence no shark tagging was done. 
SARGASSO SEA STUDIES

\section{Introduction}

$\Lambda$ number of Westward cruise tracks transect greater or lesser portions of the Sargasso Sea. Such tracks provide a unique opportunity to allow comparative studies of drastically different water masses and their of ten highly differentlated flora and fauna. The Sargasso Sea is the marine equivalent of the desert. Its perpetual state of low nutrient levels in the photic zone requires special adaptation by indigenous spectes, while its circulation allows only small scale interchanges with adjacent water types. Flotsam abandoned in the Sargasso Sea will tend to remain, including such anthropogenic nuisances or pollutants as tarballs. These may be used as indicators of man's impact on the environment on a global scale and are therefore of long term interest. Recent advances in the understanding of Gulf Stream dynamics, particularly rings or eddies that spin off from stream meanders that reach closure, suggest that these phenomena may be the one significant exception allowing greater than expected exchange with the adjacent slope water, particularly as regards the biota.

The student projects dealing with aspects of the Sargasso Sea focus on these and other aspects, especially the ever-fascinating area of the vertical migration of organisms of otherwise limited motility. 
Sargassum Weed Communities

Holly Huddleston

\section{ABSTRACT}

The purpose of this project was threefold: (1) to determine the relative percentages of the two most common types of Sargassum seaweed

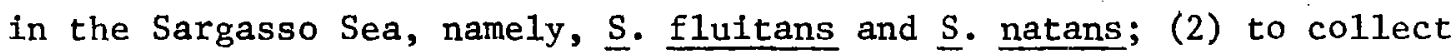
and identffy the various organisms that make up the Sargassum community; and (3) to determine whether or not certain organisms prefer one specics of Sargassum to the other. The samples were taken by both Neuston tows and by dip nets, and flora and fauna were then 1dentified. In all, six samples of $\underline{\mathrm{S}}$. natans, weighing 920 grams total with an average weight of 1.55 grams, and five samples, welghing 881 grams total with an average weight of 176 , of $\underline{s}$. fluitans were collected, signifying that neither species was more abundant than the other. Organisms living on and within the seaweed were then keyed out and counted. Certain species of Hydrozoans were found to be endemic to either $\underline{S}$. fluitans or $\underline{S}$. natans. Plumularia setaceoldes and Aglaeophenia were found only on S. fluitans, while Plumularia strictocarpa, Clytia johnstoni, Clytia noliformis, and Obelia dichotoma were found only on $\underline{S}$. natans. These differences may be due, in part, to the presence of hairy tufts on $\underline{S}$. fluitans, which may lend protection to certain species. 
Primary Productivity in the Sargasso Sea

Phyllis Dunckel

\begin{abstract}
Primary productivity in the Sargasso Sea is relatively low in comparison to northern Atlantic waters, and is dependent directly on seasonal levels of incoming solar radiation. High levels of Insolation during the summer months 1imit surface phytoplankton activity but create; viable conditions for the existence of phytoplankton to depths reaching the permanent thermocline.

Data were obtained from two locations in the North Atlantic, at $33^{\circ} 51^{\prime} \mathrm{N} 65^{\circ} 50^{\prime} \mathrm{W}$, and $41^{\circ} 29^{\prime} \mathrm{N} 65^{\circ} 45^{\prime} \mathrm{W}$ in order to investigate the relation between light penetration and phytoplankton productivity. An irradiometer was used to indicate light intensity at different depths, and water samples were obtained from depths up to 800 meters for analyses of chlorophyll-a concentrations.

Data compiled for the Northern Sargasso Sea station (H-6) showed the optimal level of phytoplankton activity was between 300-400 meters, and that surface activity was greatly diminished. At station $H-7$ in the (iulf Stream, phytoplankton activity was greatest at the surface and decreased to undetectable levels at 300 meters; concentrations of ch1orophy11-a in the Sargasso Indicated phytoplankton activity to 800 meters. Light intensity decreased much more rapidly at more northerly stations, though extrapolation of data from H-6 implied that light was available for phytoplankton activity at 400-500 meters.

The overall trends indicated by the data support the hypothesized relation between primary productivity and solar radiation. Concentrations of nutrients in the water column, as investigated on $W-52$ by Patricia Hansen, provide supporting evidence for the conclusions of this study.
\end{abstract}


Copepod Populations in Neuston Tows

Marina S. Finch

\section{ABSTRACT}

During W-52 I calculated populations of calanoid copepods collected in a series of 16 noon and midnight neuston tows taken in the Sargasso Sea. By counting a six milliliter sample from each 400 milliliter sample collected, I arrived at a population count for each neuston tow. For each sample data were collected to determine the state of the sea, the percent cloud cover, relative brightness (for the night-time samples), ship speed, and water temperature. I conclude that the copepod populations at the sea-surface clearly increases at night-time. An average 6 milliliter night sample contained 200 copepods, as compared to a day sample average of 8 copepods. Secondly, there appeared to be a slightly higher number of organisms present at the surface on an overcast day than on a clear day. These samples contained seven and ten copepods, respectively. There was no discernible correlation between the relative brightness (e.g. the presence of stars and moon) at night and the populations. There was no apparent correlation between the turbulence of the sea surface and the number of copepods collected. These data support the theory of vertical migration in copepods. 
The feeding habits of euphausiids in the Sargasso Sea

Ruth A. Gorski

\section{ABSTRACT}

The feeding habits of euphausiids in the Sargasso Sea were studied via microscopic observation and quasi-quantitative volume estimates of stomach content in order to identify differences in diet and feeding times between species. Special attention was given to the presence or absence of an elongated thoracic appendage to determine If this morphologic adaptation affected the euphausiid diet.

Although only one meter net tow was successfully completed, it contained 9 different species from 5 genera. Direct observation revealed that volume of stomach content varled from species to species, but was consistent within a species -- i.e. every individual of Stylochetron elongatum had zero stomach volume, every individual of Thysanoessa gregaria had a full stomach. These observations imply diurnal differences in feeding habits between species. Color of stomach content varied from transparent to dark green, indicating dietary differences. The contents, however, were not readily identifiable.

Two species from a slope water tow were examined and copepods were identified in the stomachs of Thysanopoda acutifrons, a species lacking a prehensile appendage. The interpretation stemming from this is that euphausiids are omnivorous, feeding on both zooplankton and phytoplankton - whichever is in abundance. The prehensile appendage, then, may represent an adaptation enabling the speries to utilize alternate sources of food through predatory methods of feeding. 
The relationship between diurnal migration and pigments in copepods Linda Carlson

\section{ABSTRACT}

The purpose of this investigation was to determine if the pigment levels of copepods at different depths are affected by their diurnal migration. Samples were taken with meter nets at three depths simultaneously, 10 meters, 150 meters, and 300 meters. This was done three times during a twenty-four hour station, 1400(noon), 2000(evening), and 0100 (midnight). The pigment was extracted by crushing the sample in an acetone and EDOH 5:1 solution. The sample was centrifuged for 24 hours and then the pigments were measured spectrophotometrically.

A teaspoon-size subsample was counted from each sample to determine the density of copepods at each depth. These counts showed the generally accepted diurnal migration pattern. The highest counts were found at $150 \mathrm{~m}$ and $300 \mathrm{~m}$ at noon. At this time the migrating copepods are below 300m level.

A volume was determined for each sample that contained a set number of copepods and the pigment was extracted. The pigment level at each depth did change with time. The dominant pigment in all samples was astaxanthin (major absorbence at $470-490 \mathrm{~nm}$ ). A high relative concentration of this reddish pigment should be found in the deeper dwelling species having an extensive migration pattern. This is reflected by the data. If the highest numeric value of absorbence is taken to be $100 \%$, the results are as follows. In the noon tow, the levels were $10 \mathrm{~m}-19.6 \%, 300 \mathrm{~m}-39.3 \%$. The low number of copepods in the $150 \mathrm{~m}$ sample of the noon tow made a reading impossible. At this time the deeper species should be at their lower migration pattern, below the $300 \mathrm{~m}$ level. The data show this with a low pigment level. The evening tow results were $10 \mathrm{~m}-42.7 \%, 150 \mathrm{~m}-12.2 \%$, $300 \mathrm{~m}-47.4 \%$. The pigment level had increased, indicating the deeper, more heavily pigmented species were moving upward. At midnight, the results were $10 \mathrm{~m}-17.5 \%, 150 \mathrm{~m}-90.0 \%, 300 \mathrm{~m}-100 \%$. The pigment concentration continued to increase showing an increase in the migration. The 10m level is low in pigment because the deeper species do not migrate a11 the way to the surface layer.

This seems to indicate that the pigment levels at different depths are related to the diurnal migration of the copepods and this technique may be used to delineate the diurnal pattern. 


\section{Introduction}

Gulf Stream meanders are capable of forming rings or eddies on efther the north, or slope water side of the stream, or on the south, or Sargasso Sea side. In the former case, warm sallne water is entrained, producing a warm core eddy or warm core ring. In the latter case the colder, less saline, but highly productive and populated slope water is entrained in the Sargasso Sea. This slope water entrainment is of great interest to the biologist for not only does it allow the study of the effects of stress caused by temperature and salinity increases as well as nutrient loss, but also it has led to speculation that this process may account for the replenishment and enrichment of the gene pool of native populations.

Knowledge of such effects must be preceded by a good understanding of ring dynamics. Of interest is the process of ring formation, know1edge of ring birth frequency, the aging of rings, and their eventual decline by mixing into the surrounding waters.

While the total number of student projects is relatively few, and the cruise track did not allow spending a great deal of time in the vicinity of rings, the following physical study and biological observations complement one another and demonstrate approaches used to enrich our understanding of rings and their possible biological role. Figure 2 shows Gulf Stream ring positions as inferred from satellite data during the cruise. 


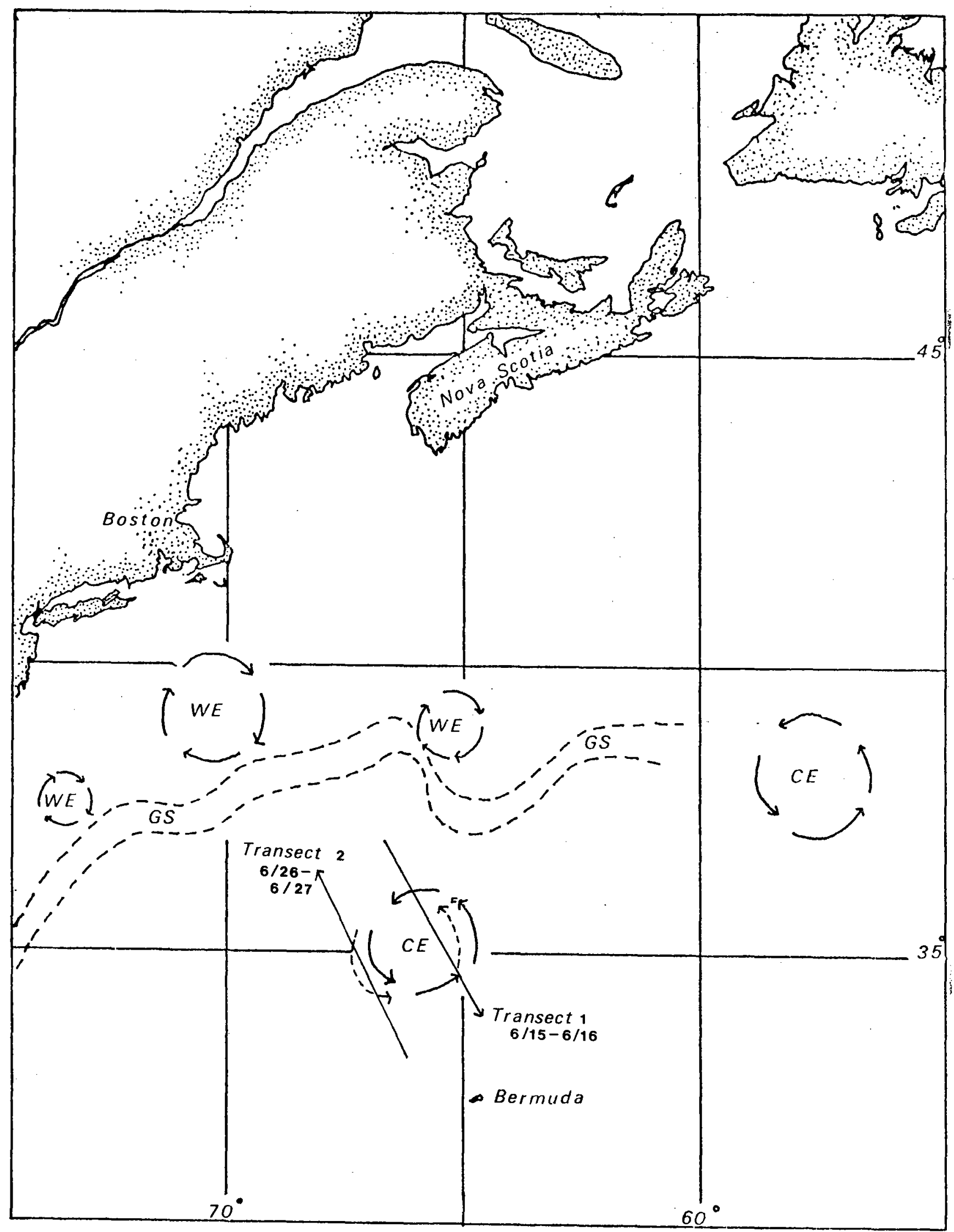

Figure 2. Track of $R / V$ Westward through a cold core ring. 
Productivity Analysis through Nutrient Measurements

patty Hansen

\section{ABSTRACT}

Leve1s of phosphorus and silicates were examined in order to compare the productivity of the Sargasso Sea and slope water.

Phosphorus was used because it is necessary for photosynthesis and is often a limiting nutrient. Silicates, which are used in the she11s of diatoms and radiolarians, are an indicator of phytoplankton population.

Water samples were taken at various depths in both Sargasso Sea and slope water. Silicates and phosphorus were determined using the Strickland and Parsons method, where reagents were mixed with the sea water samples and light extinction was measured on a spectrophotometer.

The phosphorus data show a high leve1 (13 $\times 10^{-2} \mu \mathrm{g}$-at/1 in the Sargasso Sea) of nutrients in the upper waters and a drop in the photosynthetic layer just below the surface. An increase below the level of light penetration was observed where photosynthesis no longer takes place and phosphorus is not being used. There is also a large (35 x $10^{-2} \mu \mathrm{g}-\mathrm{at} / 1$ in slope water) increase in the nutrient level at greater depths where the phosphorus is recycled. The profiles are similar in the two water masses but the nutrients were at higher levels in the slope water.

The silicate data differ greatly between the Sargasso Sea and slope water. The slope water has a very high concentration $(1.0 \mu \mathrm{g}-\mathrm{at} / 1)$ of silicates at the surface that drops off steadily with depth. These data support the contention that the Sargasso Sea is less productive than slope water. Figure 3 summarizes the findings and allows comparison to the findings from chlorophyl1-a measurements. 


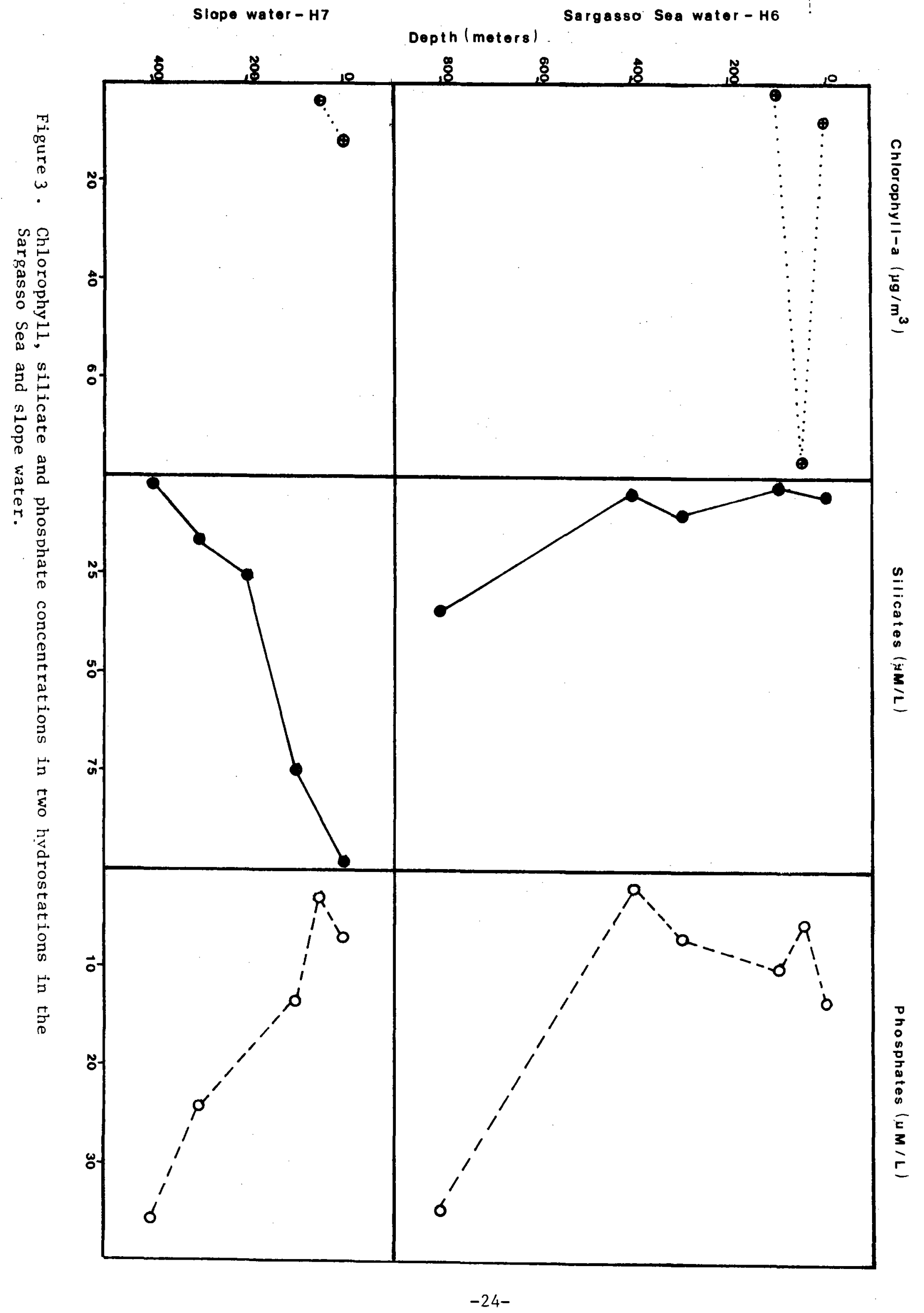


Vertical Migration of liphaustds

I,eah George

\section{ABSTRACT}

Vertical or diurnal migration is a widespread phenomenon found throughout the marine environment. The purpose of this investigation was to study the relationship between the magnitude of vertical migration. and the intensity of light in the water. The organisms used in this study were Euphausids. These organisms had previously been observed to migrate diurna11y.

Data were obtained through the use of simultaneous meter net tows. Nets were placed at 10, 150, and 300 meters below the surface and towed for thirty minutes. Two subsamples of $7 \mathrm{ml}$. each were taken from each net and six different tows were analyzed. The tows were performed at various times of day and night. An underwater irradiometer was used to determine the intensity of light at the depths towed.

The results clearly showed that the Euphausids are higher up in the water column at night than in the daytime when the light levels are greater. There were not enough data gathered to indicate what the optimal light intensity is. The number of Euphausids at the 150 meter level showed the greatest variance with the time of day the tow was done. The range was from 0 in the afternoon tow to 1.5 per $\mathrm{m}^{3}$ in the late night tow. A11 eight of the species of Euphausids observed appeared to migrate. 
Cold Core Dynamics

Shawn Gallagher

ABSTRACT

On W-52 a cold core eddy was transected on two different occasions in an effort to study the dynamics of a cold ring. Information on surface currents, thermal structure, and salinity characteristics was collected during each transect. A current vector diagram was constructed for each passage using Loran " $\mathrm{C}$ " fixes and the ship's 1og. It was determined from this information that currents within the eddy were cyclonic and ranged from 1 to 3 knots (Fig. 4 ). Data showed no significant radial patterns due to poor resolution of technique. Approximate centers were located on each passage and a westerly movement along the 36 th parallel was determined. The core moved with a velocity of approximately 0.05 knots. This is slower than earlier velocities determined from NOAA satellite information. Bathythermograph traces were made on each transect (Figs.5 and 7 ) and the age of the core was determined to be 58 days by using the $17^{\circ} \mathrm{C}$ isotherm depression method. This age agrees with NOAA satellite information. Surface salinities revealed concentrations of $35.8 \%$ near the center and $36.4 \%$ at the outer portion of the eddy. Results of drlit observation during the second transect are shown in figure 6 .

lurther efforts should be made to study eddy dynamics and the biology of decaying eddies. Particular attention must be paid to full cooperation between nautical science and blological science departments on collecting accurate and meaningful data. 


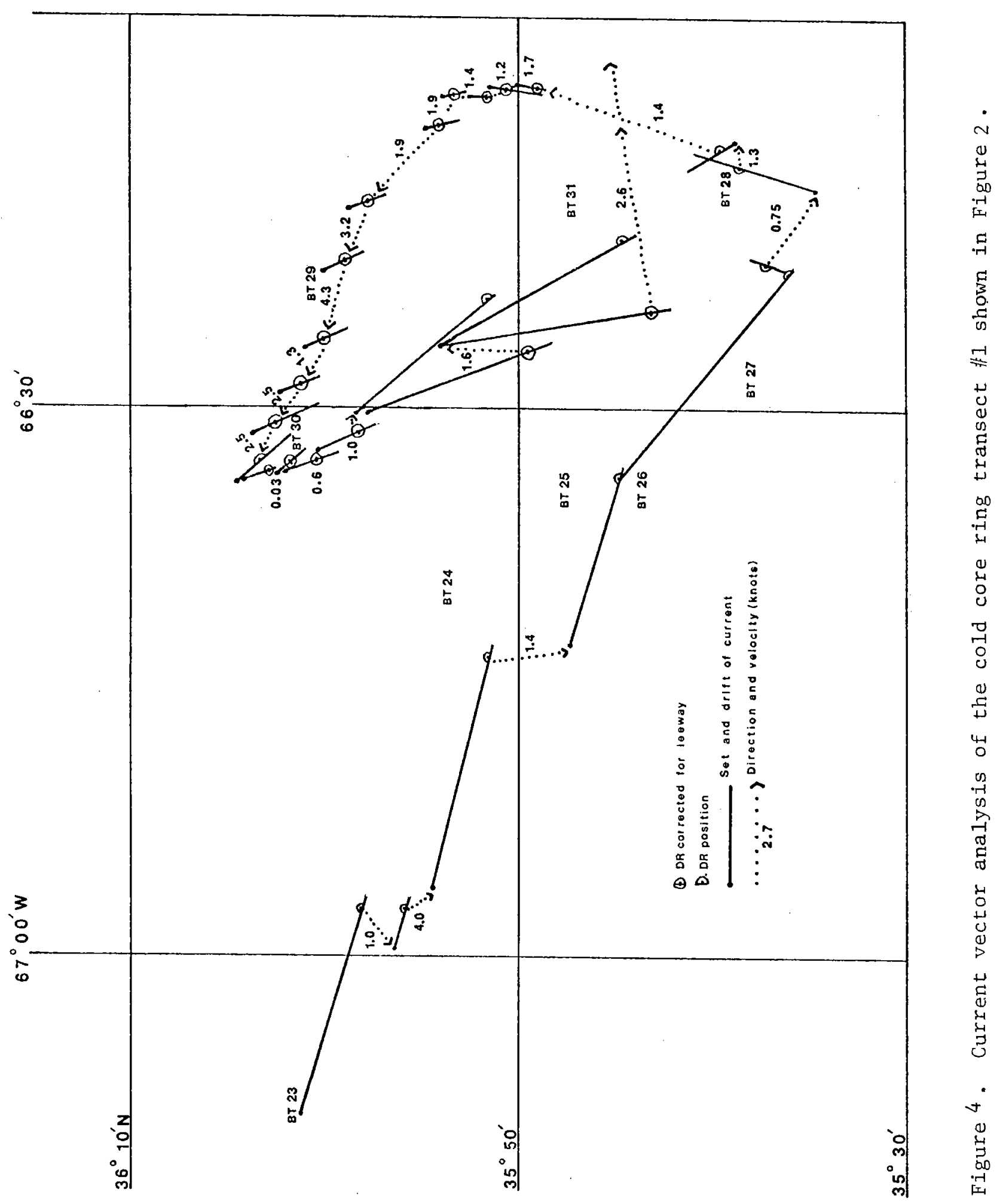


Depth in meters

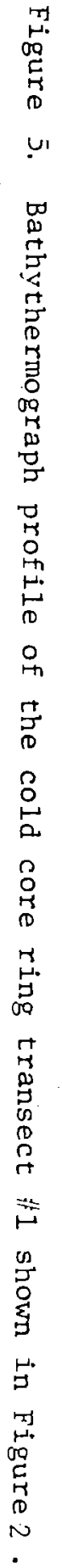

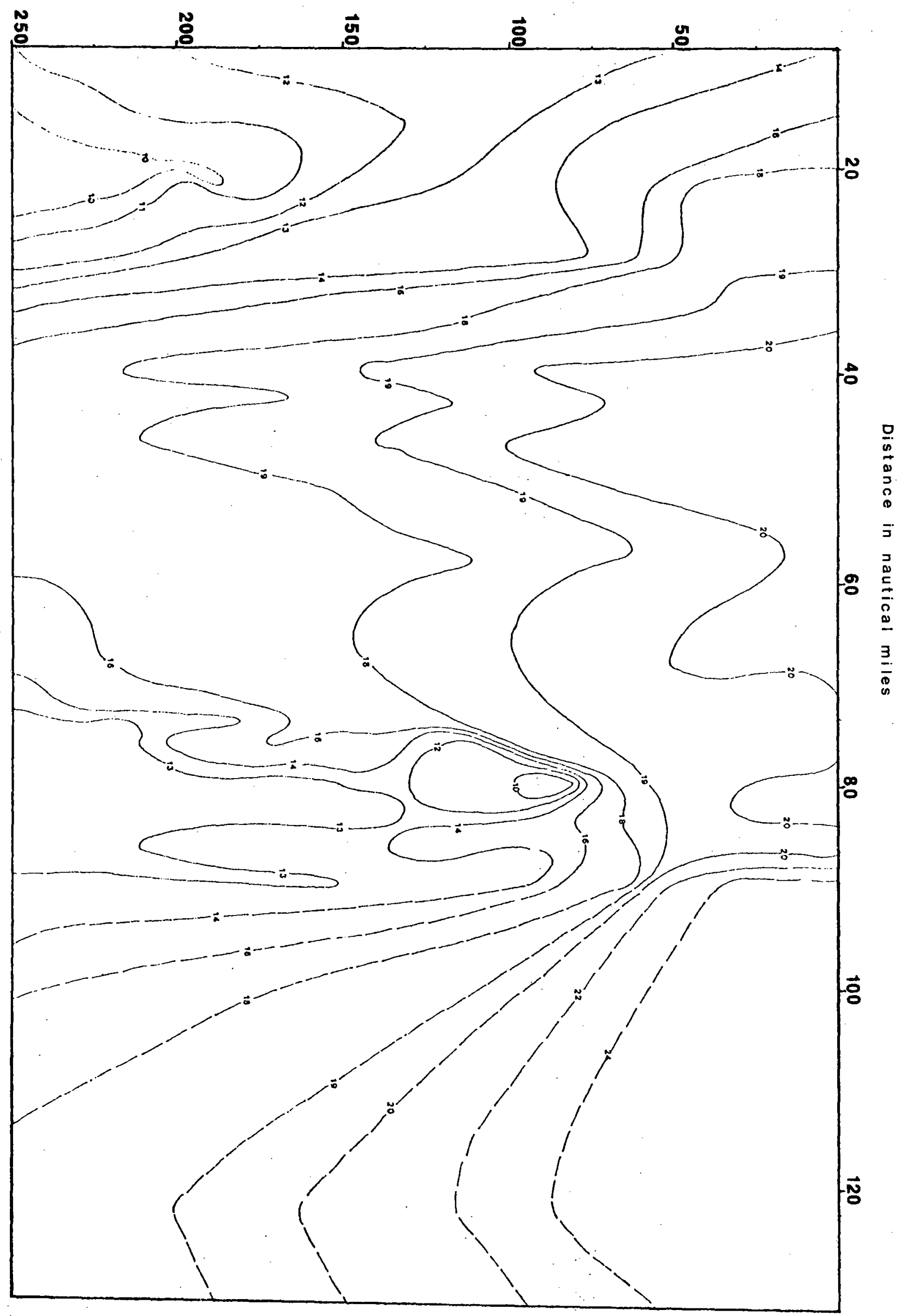




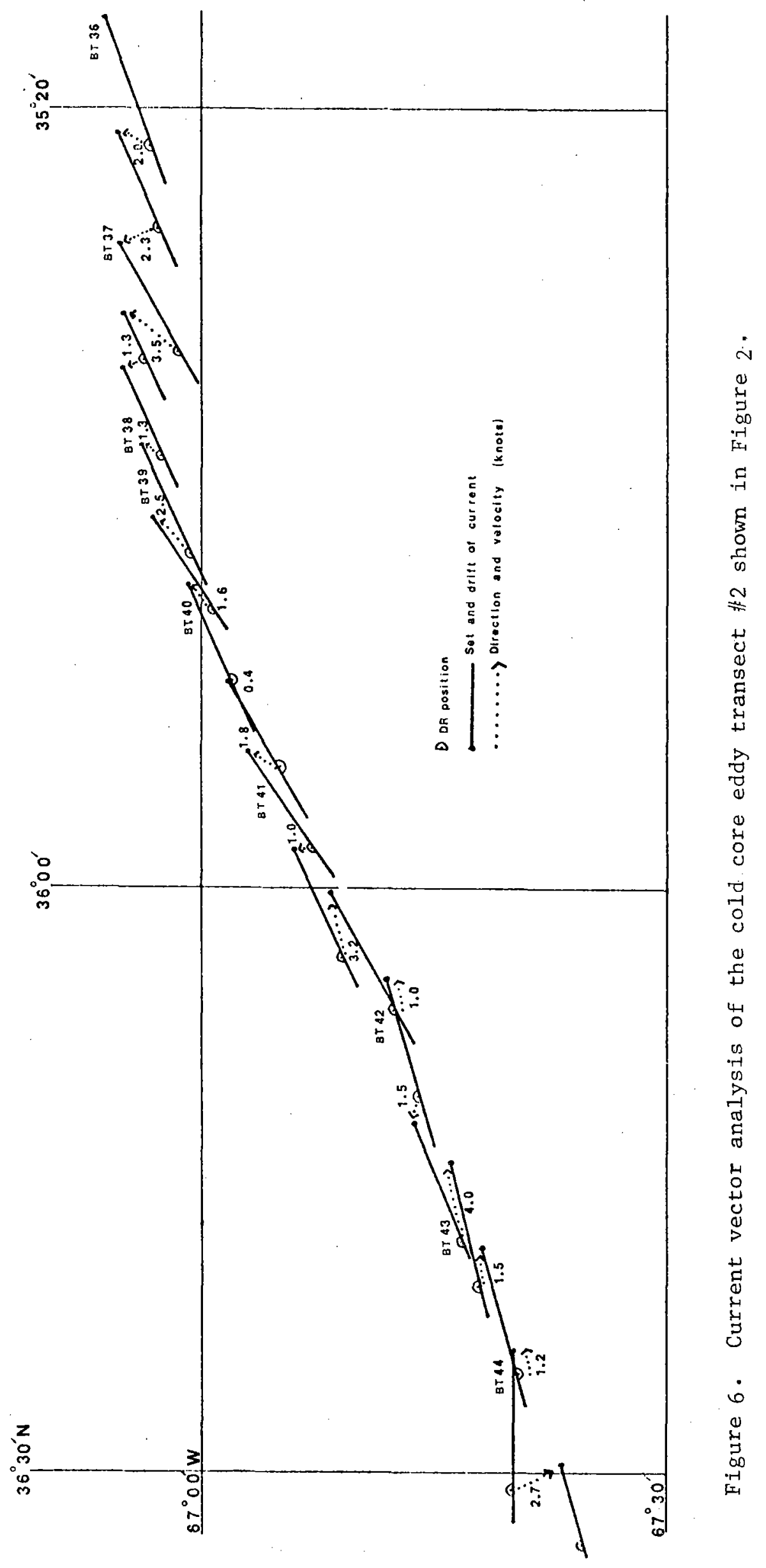




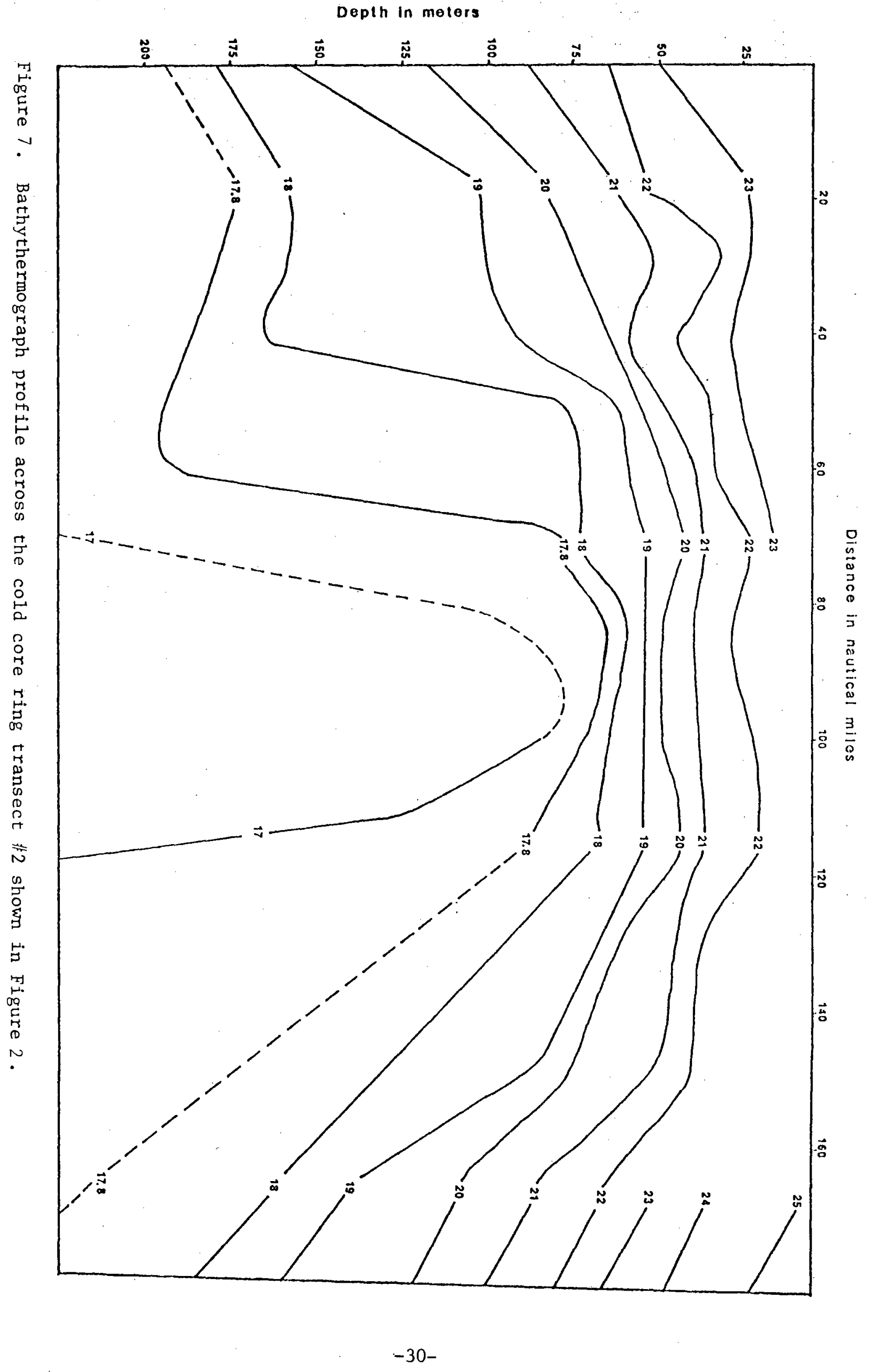


The Effects of Cold Eddies on the Vertical Migratory Behavior of the Lantern Fish

Laura Herr

\section{ABSTRACT}

An attempt was made to study the effects of cold eddy isolation on the vertical migration patterns of lantern fish. Simultaneous tows at 30,150 and 0 meters, taken at various times of day in the Sargasso Sea, a cold eddy, and slope water were examined for numbers and distribution of $\mathrm{fish}$. More fish were found in slope water than in the cold eddy, with the least being collected in the Sargasso Sea. Of the fish collected, more were found in the upper nets in slope water, while most of those collected in the Sargasso Sea were caught in the deepest net. Most of the $f$ ish caught in the cold eddy were in the larval stage while adult forms were more common in the Sargasso Sea and slope water. The cold eddy data indicates a migration pattern deeper than that in slope water, and shallower than that in Sargasso Sea water. The differences in migration patterns are attributed to changes in light penetration, which is directly affected by the blological productivity of the water mass (see Figure 8). Temperature may also be a factor. Lantern fish may move their migration pattern to greater depths to avoid the warm, invading Sargasso Sea water. More work should be done to try and correlate changes in vertical migration patterns with the changing temperature structure of an aging eddy. 


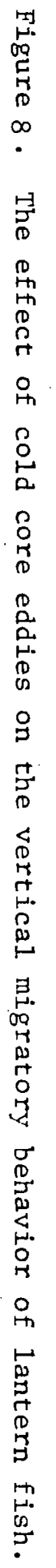

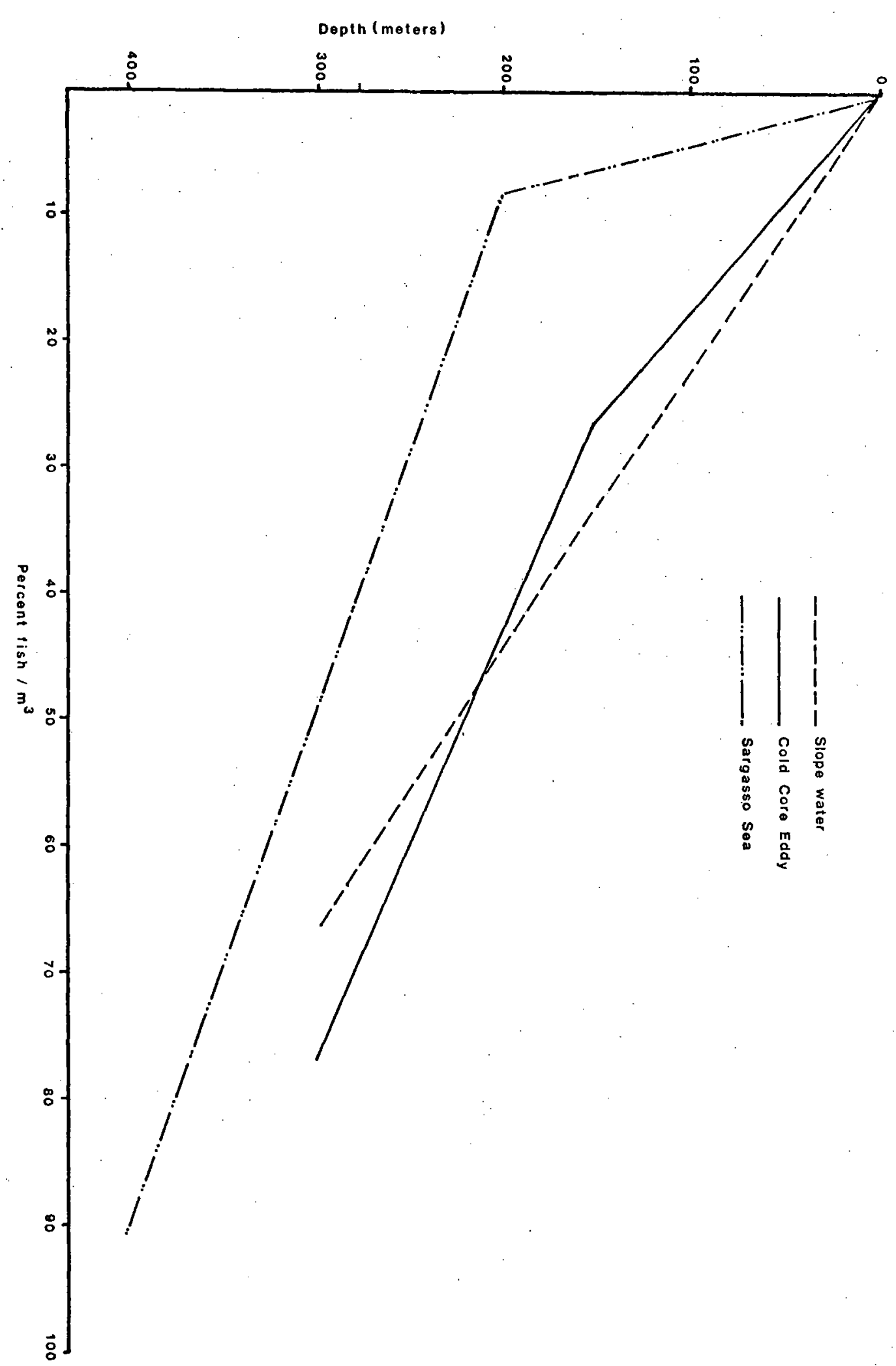




\section{STUDIES ON GEORGES BANK AND ADJACENT WATERS}

\section{Introduction}

The student projects that follow represent perhaps the greatest range of interests, disciplines, and applications of scientific methodology. The waters and underlying strata not only lend themselves to diverse studies, but almost force it: Why does the bank exist? How do you explain its shoal depths? What past events have shaped the continental shelf here? Why are the waters so productive? What resource potential does the Bank represent? What threats exist to this resource? How much of this threat comes from human sources, how much is part of nature? What, if anything, should be done about it? These and many more questions force themselves on the careful observers studying both the scientific and technical literature and transiting its waters -- even the surface is agitated by wavelets reminiscent of tide rips, and birds and marine populations are an obvious presence.

While the projects could not possibly address even a small portion of issues worth raising, they do reflect concern and critical thinking and are a good representation of what can be achieved given the limitations of shipboard analysis only, the ever-present impact of adverse weather, and the limits of schedules and deadlines. 
A Sedimentological Analysis of the Continental Shelf of New England Andrea Westinghouse

\section{ABSTRACT}

The sediments of the continental shelf and slope of New England have been sampled at random, for the purpose of describing a range of depositional environments and to relate specific environmental processes to grain size. Gravity cores as well as surface grab samples were taken at various representative locations to be used for analysis. The samples were dried, divided into two 60 gram samples using a torsion balance, sleved through five gradations of mesh sizes, and finally weighed to determine a grain size distribution relative to each sample. Gross analysis of the sediments was also undertaken with the aid of compound and dissecting microscopes. Observations were made to consider such characteristics as general 1ithology, angularity of grains, the nature of the biogenic fraction, color and texture.

There appears to be very little significant accumulation of sediments occurring in recent geologic history; they are primarily relict on the shelf and slope. The Gulf of Maine as well as the slope area contains fine grained sediment, with the mafority in the .250 to $.450 \mathrm{~mm}$ range, approximately $80 \%$ of the 60 gram fraction. Histograms for both environments were greatly similar with respect to grain size distribution. It is probable that the fines are being winnowed from Georges Bank, an area of high energy. The sediment of Georges Bank is richest in the $.250 \mathrm{~mm}$ range and up to gravel size. Coarse sand in the $.250 \mathrm{~mm}$ fraction dominates the sample, comprising roughly $65 \%$ of each sample. Silt and clay fractions were negligible. A high percentage of the sand on the banks was quartzitic, somewhat unusual for a glaciated area which should be more arkosic. About $20 \%$ of the sand fraction was found to be distinctively well rounded and iron oxide stained, indicating subaerial exposure. This seems to indicate considerable reworking of sediments on the banks in view of the heterogeneity of the sediments, as the remaining sand fraction was angular and free of oxide coating.

Georges Bank then is an area of very high energy resulting from strong tidal currents, storms, and wind generated currents. Tidal current vector diagrams of the region support this. The north-south vectors are 
greatest, which coincides with the similar orientation of grooved topography on the shoals. Where vectors are more equidistant, the more typical pitted "kettle and kame" topography remains irregular, as seen in the Gulf of Maine. There was a considerable amount of coarse materlal found in the Gulf and slope, including one large glacial erratic, cobble sized. This is probably material being washed from Georges Bank, most likely via hurricanes creating sufficient velocity to carry coarse matertal off the banks. The shelf break had a greater proportion of $4.00 \mathrm{~mm}$ to $.250 \mathrm{~mm}$ coarse material, $25 \%$ more than the slope sample. Hence, proximity to the banks is indicated by increasing coarseness. Findings are graphically represented in Figure 9 .

Further study is needed in the productive Georges Bank region, with the intent of gathering control data prior to the initiation of oil drilling on the shelf. It will be useful to obtain information dealing with the depositional regime, sediment characteristics, and currents as we11. The impact of oil seepage and toxic drilling muds can then be accurately monitored as the drilling process progresses. 
' Weight in grams

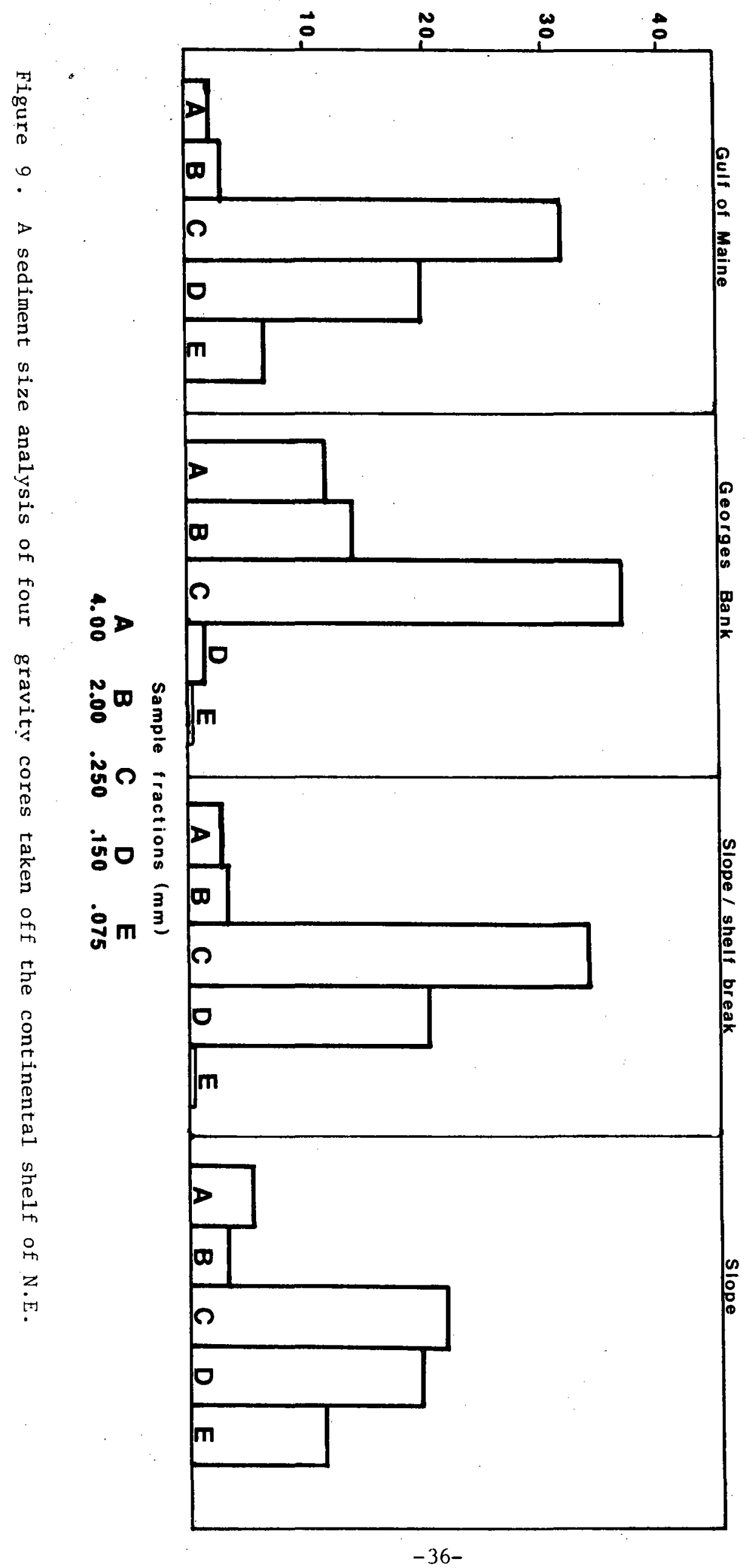


The Relative Abundance of Benthic Foraminifera in a Transect of the Continental Slope Southeast of Cape Cod

Mike Schulze

\section{ABSTRACT}

Benthic foraminifera have been used widely to typify marine environments. This investigator attempted a coretop study to define the range. of a benthic foraminifera, Uvigerina peregrina. This assemblage, noted by Miller and Lohmann, has been used as a paleo-environmental indicator. T'wo gravity core stations were attempted $-1500 \mathrm{~m}$ and $650 \mathrm{~m}$. Only the $1500 \mathrm{~m}$ core was successfully obtained. The coretop was then analyzed and it was found that the relative abundance of $\underline{U}$. peregrina was $63 \%$. This relative abundance was then plotted on a Relative Abundance vs. Depth graph, together with the Miller and Lohmann data point at $975 \mathrm{~m}$ that showed a relative abundance of $25 \%$. The point at which the joining line intersected the axis should be the upper depth range of $\underline{U}$. peregrina. The graphically interpolated upper range was determined to be $600 \mathrm{~m}$. Above this depth, it is inferred that the relative abundance of $\underline{U}$. peregrina will not exceed $2 \%$ (see Figure 10). 


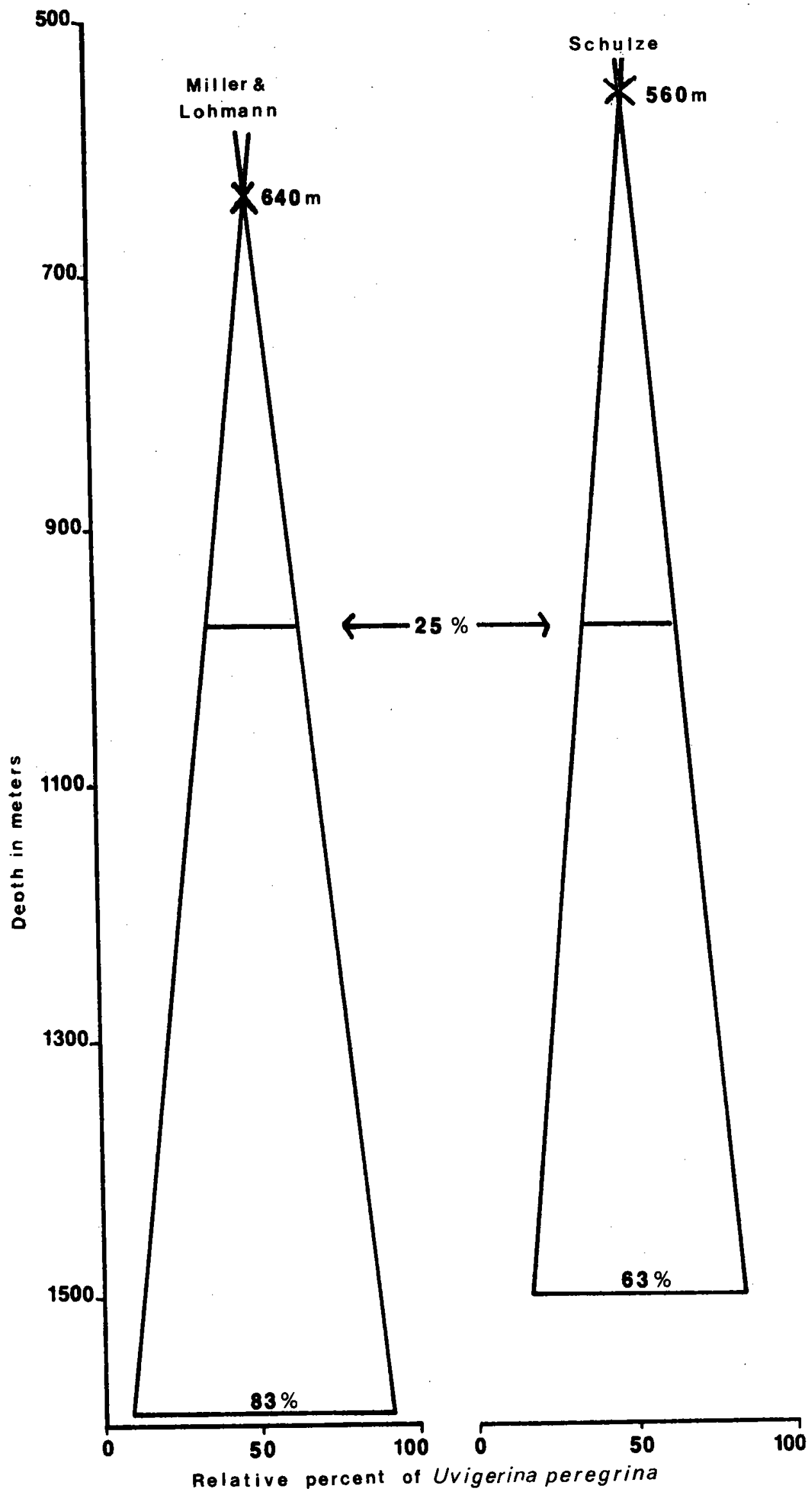

Figure 10. Depth versus the relative abundance of Uvigerina peregrina from published data (Miller \& Lohmann) and work aboard the Westward. 
Goniaulax off the Nova Scotian Coast

Frank Schuh

\section{ABSTRACT}

In 1972 a population of Gonfaulax was located in the Southeast corner of the Gulf of Maine. In an effort to locate the parent population of this bloom, a total of nine phytoplankton tows, mesh size $.05 \mathrm{um}$, were made. It was hypothesized that the parent population may be located off the Nova Scotian eastern coast, the cyst stage being carried by subsurface currents into the Gulf gyre. Outward transport of the cysts via upwelling occurs in the Southeastern corner of the Gulf.

Alternate hypotheses by other investigators as to the location of the parent population place it either in the Bay of Fundy or in the estuaries along the coast. Five samples were taken along the southeastern edge of the Gulf to serve as controls. Three samples were taken along the eastern shore of Nova Scotia, and one in the northeast channel to the Gulf. One Gonfaulax sp. was found in the control area. None were found in the test area. The low number in the control area may be explained by the relatively low numbers of Goniaulax during non-bloom periods. Finding no Goniaulax fails to prove that a population exists in the sample area. However, the population may have been in the benthic cyst stage during sampling. Further research will need to look at the sediments of the area in order to more thoroughly examine the hypothesis. 
Attracting Cod using their Sense of Smell

Carol Sohon

\section{ABSTRACT}

On July 2, 1980, aboard the R/V Westward, an experiment was done testing the feasibility of attracting cod by use of bait appealing to their sense of sme11. Previous work by others consisted largely of tank testing. Aboard Westward seven different solid baits, on twelve different lines, were used. The bait was contained in nylon bait bags, surrounded by hooks and suspended on thirty-fathom jig lines. Standard jigs without balt were also used at this time. Over the course of five hours, the following results were obtained.

$\begin{array}{cc}\text { Standard jig lines returned } & \text { Baited lines returned } \\ 1 \text { Silver Hake } & 1 \text { Moon Snail } \\ 10 \mathrm{Cod} & 1 \text { Dogfish } \\ & 1 \text { Cod }\end{array}$

Work by Bateson indicates cod is a species that finds food through smell. Results of this experiment indicate cod primarily use their sight to find food. There was agreement with Bateson to the extent that the baited lines did catch two fish. This suggests cod use their olfactory organs in finding food, but do not appear to rely primarily nor solely upon it.

The haddock intestine was the most successful bait. None of the others had any return. The reasons for such poor results could be:

1) Size and/or shape of the bags made it difficult for the fish to bite.

2) The odors from the bag were not strong enough.

Further testing using more concentrated odors in smaller bags might yield better results. 
The analysis of the stomach contents of fish

Amy Knowlton

\section{ABSTRACT}

Now that the implementation of oil drilling is a reality, commercial fishing on Georges Bank is facing serious problems. The oncoming oil drilling may have a direct effect on the fish themselves and may also alter the food chain of which the fish are an integral part. In order to study long term effects, controls are needed to provide a means of obtaining comparative data. For my baseline study I chose to analyze the stomach contents of fish caught during the cruise.

The stomach contents of two species of fish, Melanogrammus aglefinus (Haddock) and Gadus morhua (Cod) were preserved in formalin and later analyzed. Both of these species are bottom fish which commonly feed on benthic fauna including scallops, clams, squid, small $\mathrm{fish}$, and a variety of zooplankton. Five samples of M. aglefinus were brought up in the otter trawl at 0230 on July 1,1980 at $42^{\circ} 01.6 \mathrm{~N}$ and $66^{\circ} 23.3 \mathrm{~W}$. The length of the $\mathrm{fish}$ ranged from $37.1 \mathrm{~cm}$ to $42.5 \mathrm{~cm}$, and their age ranged from 2.5 years to 3 years. There was surprisingly little to be found in their stomachs, the contents consisting of five or six amphipods $(.25 \mathrm{~cm})$ or an annelid worm at the most. Perhaps the haddock feed only during the day, which would account for thelr empty stomachs.

Later that same day, eleven samples of Gadus morhua (cod) were caught at different times using the jigging technique at $41^{\circ} 42.2 \mathrm{~N}$ and $66^{\circ} 55.5 \mathrm{~W}$. The stomach contents of these fish were also preserved in formalin for later analysis. The length of the cod ranged from $52.1 \mathrm{~cm}$ to $102.2 \mathrm{~cm}$ with an age range of 3 to 9.25 years. Analysis of the stomach contents revealed a great deal of variability, both in the amount and in the content, but there was no correlation of amount of food to the age of the fish.

Because there was 1ittle food in the haddock stomachs, no representative list is given. In the case of the cod, results include a separate list of the stomach content components for each fish. These lists can be used during future cruises as a reference for monitoring environmental stress. 
Effects of fish age on numbers of parasitic copepods

Karen Tierney

ABSTRACT

'The presence of parasitic copepods is an extremely common occurrence In most marine fish. It is hypothesized that as the age of the host increases, so will the number of ectoparasites.

Three different styles of flshing were utilized. We caught nothing on a longline, five haddock (Melanogrammus aglefinus) with an otter traw1, and eleven cod (Gadus morhua) with jigs. The fish were of various ages. Fish ages were determined from known age/length relations. Trends in the data indicate that ectoparasite burden does increase with host age, at a confidence level of $95 \%$ (Fig. I1). Abundance of copepods on older fish may be attributed to several factors: less competition for space, greater volume of water passing over gills, and longer accumulation time. The major parasite collected was Caligus rapax, along with a few Clavellisa scombri. The aspects of host-parasite interactions are important to understanding the ecology of a changing environment such as Georges Bank threatens to become. 


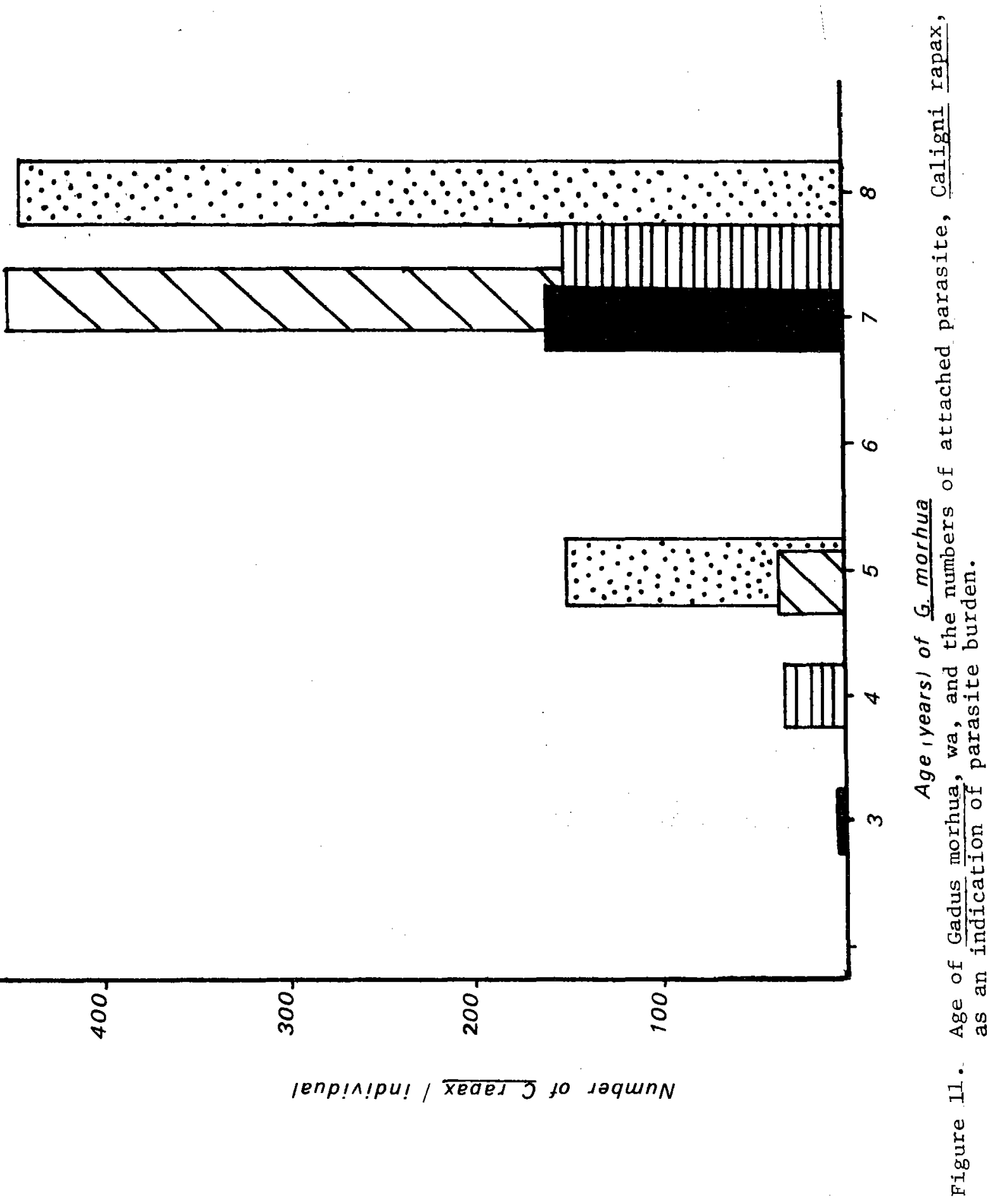


Temperature and salinity differences and the cetoparasitic burden of Gadus morhua

Mary Kyle Dyer

\section{ABSTRACT}

Ecto-parasites are quite common on the bodies of fishes. Whether they are harmful or not is dependent upon the type of copepod. Copepods are known to be both free living and parasitic. This project was designed to measure the effects, if any, of differences in temperature and salinity on Georges Bank as related to the ecto-parasitic burden of Gadus morhua, the codfish.

Two stations were done within 24 hours using two different fishing methods. The otter trawl was set to a depth of 48 fathoms on a sandy bottom and brought back five Melanogrammus aglefinus, haddock, but no cod. Nansen data from 48 meters, half the water depth, recorded a temperature of $8.60^{\circ} \mathrm{C}$ and salinity of 34.465 parts per thousand. However, what is even more important to this discussion is that there were absolutely no parasites present on any of the 5 haddock. The position for this station was logged at $42^{\circ} 01.6^{\prime} \mathrm{N}, 66^{\circ} 23.3^{\prime} \mathrm{W}$.

Station $\# 2$ was undertaken at a position of $41^{\circ} 42.2^{\prime} \mathrm{N}, 66^{\circ} 55.5^{\prime} \mathrm{W}$ twelve hours after the otter trawl was completed. At this station jigging was employed as the means of catching fish in 35 fathoms of water. Nansen data from 35 meters showed a temperature of $10.09^{\circ} \mathrm{C}$. Salinity stayed the same at 34.465 parts per thousand. Of the two methods jigging was most successful. Eleven cod were caught, all of which carried at least one species of parasitic copepod.

Two species of copepods were found. (1) Caligus rapax moved freely over the entire body and in the mouth of the fish. (2) Clavellisa scombri was found anchored in the flesh around the base of the fins, in the roof of the mouth, and on the gills.

Due to the fact that the fish were caught only in one location results cannot be considered complete. The two species of ecto-parasitic copepods on the cod ranged drastically in numbers found. Numbers exceeding 400 of the Caligus sp. were found on the largest fish (40.25") caught. However, the greatest number of $\underline{G}$. scombri counted on one $f i s h$ was 11 , and this was 
on a fish of only 22". Age, calculated by length, seemed to be the controlling factor in determining the increasing number of parasites present. Should the crulse track allot more time for work on Georges Bank with more stations, i.e. differing depths, different bottom types, and with better geographic spacing, perhaps temperature and salinity analysis would be more significant. 
The Immunological Reactions of Gadus morhua to the Infection of Porrocaecum decipiens

Paul Berkner

\section{ABSTRACT}

W. F. Templeman, in an extensive study of the groundfish in and around the Newfoundland area, found the larval nematode Porrocaecum decipiens in the flesh of Gadus morhua (Atlantic cod) and other fish native to the area. These parasites were found to Infest up to $25 \%$ of the total population of $G$. morhua caught by Scott and Martin in a paralle1 study done on the Grand Banks. The question then is, what percentage of the commercial fisheries is infested with these parasites? Although the parasites are harmless to man when cooked, they are, however, aesthetically unacceptable for commercial sale.

The other question is, is there any physiological reaction of $\underline{G}$. morhua to $\underline{\mathrm{P}}$. decipiens? More specifically, are there any immunological reactions in the blood, such as an increase in the lymphocyte count and a decrease in the erythrocyte count? This is what I tried to examine in my study of $\underline{P}$. decipiens in $\underline{G}$. morhua. We caught eleven $\underline{G}$. morhua, three of which were carrying $\underline{P}$. decipiens. The blood counts obtained from the smears done on each individual fish showed a difference in the lymphocyte and erythrocyte counts of the fish with parasites and of those which had no parasites. There are, however, no definite conclusions which I can draw from this except that the counts were different. This is due to a number of reasons, the first is that the sample size was too small to do any significant comparisons between the fish with parasites and of those without; and secondly, there were difficulties in my technique. In some cases, the cells weren't stained well because the stain wasn't applied immediately after the smears were made. In others my ability to distinguish minute differences in the two types of cells was not adequate for accurate identification. However, I do feel that this project should be continued on subsequent Westward voyages. I feel that an adequate study can be done which may show some immunological reaction by $\underline{G}$. morhua to $\underline{P}$. decipiens, which would be quite significant since no prior study has examined the correlation of parasite immunological reaction in marine vertebrates. 
Introduction

There is no demarcation where marine science leaves off and nautical science begins. Aboard Westward the interrelationship of all factors of the marine environment is stressed - the study of ocean or tidal currents is the province of the physical oceanographer and remains of vital interest to the mariner. The student projects categorized here fit because they clearly illustrate this principle. One may ask how a galley design or a ship's hydro-generating plant meet these criteria, but the methods employed are those of applied sclence and engineering, and the benefits from such work to the comfort and efficlency of the oceanographer are easy to understand for those who know the rigors of life on a small research vessel. 
Forecasting Local Weather from Surface Observations

Brad K. Linsley

\section{ABSTRACT}

With the complexity of professional forecasting and the high price of electronic equipment, it is possible to predict local weather from fust surface observations. This type of forecasting would be very useful to the low-budget ocean sailor. Surface weather observations were taken twice daily from June 15 until July 8, 1980. Meteorological rules were applied to low and high pressure systems. Similar rules were also used in frontal analysis. These rules can be found in any meteorology text. The books I used were: Meteorology, 3 ed., William L. Donn, McGraw-Hi11 Books, 1965; and Oceanography and Seamanship, William G. Van Dorn, Dodd, Mead \& Company, 1974. Details of data collected and analysis are summarized in Table 6 .

Two sets of observations were recorded, at 1300 and 1700 hours. The forecast was made after the second set. Twelve hours later these forecasts were checked against the present weather, fudging the accuracy was done after July 8 th. To assess the accuracy of the forecasts, I had to take into account the many variables involved. Of the eighteen days of forecasts, $60 \%$ were correct and $20 \%$ incorrect. On the remaining days, about half the forecast was correct and the other half was incorrect. These figures show that if the small craft mariner is given some basic meteorological rules and the understanding to use them, then he/she can forecast local weather while at sea. 
TABLE 6

\section{Data Collected}

1. time and day

2. barometer (tendency)

3. clouds (percent, forms, direction)

4. wind (speed and direction)

5. visibility

6. temperature (air, sea, wet bulb, dry bulb when needed)

7. sea conditions (swe11 height and period)

Forecast (12 hour)

1. Barometer reading

2. Wind speed and direction

3. Precipitation

4. Cloud forms and percent

5. Sea conditions

6. General weather 
Project: The Use of Underwater Lights for Swordfishing

Kevin McGrath

\section{ABSTRACT}

This project was a study to determine whether swordfish (Xiphas gladius) are attracted to underwater lights when used on a longline. I feel that increased longline productivity due to the use of lights would be of value to the commercial fisherman, because of the minimum of gear modification and the small increase in total gear cost that the lights would require. The increase in gear cost would be offset by the slightest increase in productivity.

Two longlines were made, each with thirty baited hooks located fifteen yards apart. "Cylume" underwater light sticks were attached to fifteen hooks on one section and the other section remained unlit. There was a separation zone of 100 yards between the two sections. The line varied in depth from twelve to twenty-five fathoms. Both longline sets were tracked by two buoys, one on each end of the 1ine. Each buoy carried radar reflectors and strobe lights. The first set was baited with squid and the second set was baited with mackerel.

No fish were caught on either of the sets. The first set was made in Corsair Canyon on the northern side of the 100 fathom line. The temperature of the upper twenty-five fathoms was approximately 13 degrees centigrade. The squid on the lit set were completely stripped from the hooks. The unlit set had three whole squid remaining and pieces on all the other hooks except for one, which was stripped. The second set was made in the Gulf of Maine, in 100 fathom water with a temperature range of 14.5 to 07 degrees centigrade in the upper twenty-five fathoms. There were eight hooks on the lit section that were either entirely or partially stripped of the bait. Only one hook on the unlit section was stripped.

I have concluded that the lit sections on each set attracted schools of small fish. Although no swordfish were caught, I feel that the attraction of the small fish by the lights is important. Swordfish are known to feed in schools of fish and are attracted by them. Thus the swordfish are more apt to bite on a lighted hook due to the 1ight's attraction of bait fish. Further attempts at using underwater lights on the longline should definitely be made. The more of ten the lights are used, the more accurately their efficlency will be tested. 
Birds as an aid to navigation

Gwenn Scott

ABSTRACT

On the cruise to Bermuda and to Nova Scotia, I recorded the positions of coastal, land and migrating birds that were obseryed. I also at tempted to record their directions of flight in an effort to determine whether the use of their migration patterns and daily flight habits could be considered to be an accurate or even plausible method for plotting a course to 1and. I excluded pelagic bird directions and daily flight habits.

The data proved to be very scant as the number of coastal and land birds sighted was very low. However, 45 out of 52, or 90 percent of the coasta1, land and migrating birds were seen within 100 miles of land, indicating that they are a means of establishing an approximate range to land. I. was only able to record the directions of flight from 13 of the 52 birds sighted, or 25 percent. Out of the 13 birds, 10 were either explainable by their daily flight habits or heading toward land. The remaining 3 were circling, suggesting they were feeding (see Table 7). The low number of birds from which I was able to determine direction indicates they are not a reliable aid in terms of providing information on bearings to the land. Coastal and land birds are also unreliable to use for navigation due to the small number encountered. 


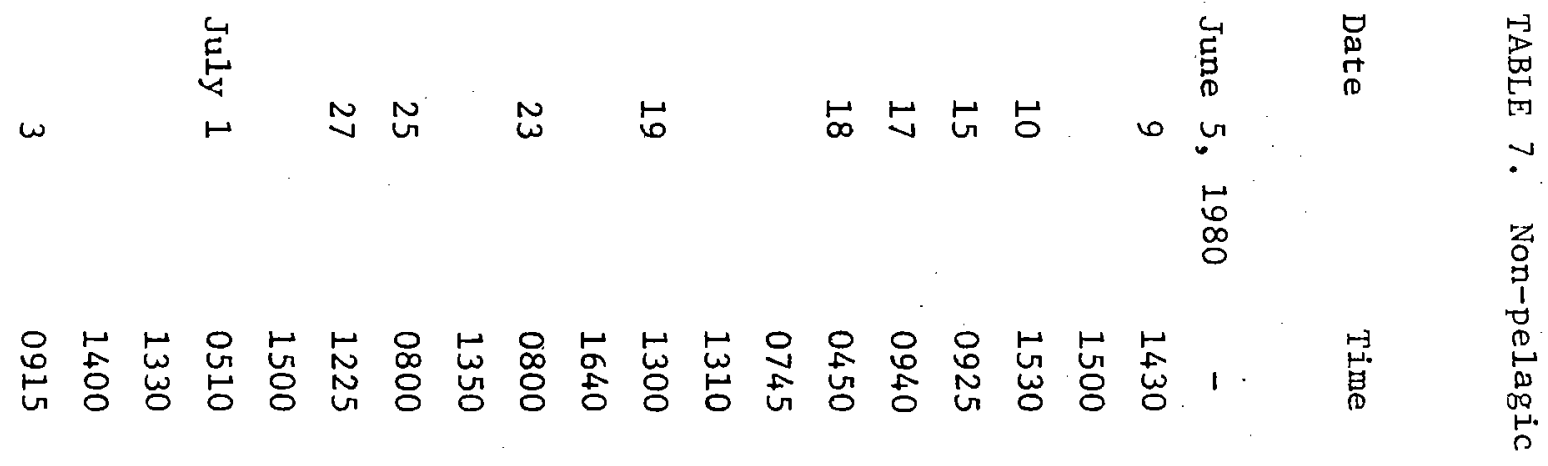

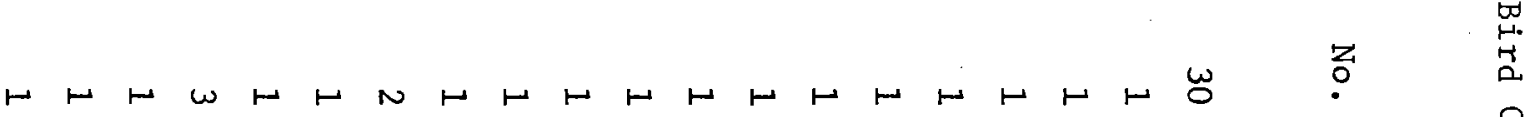

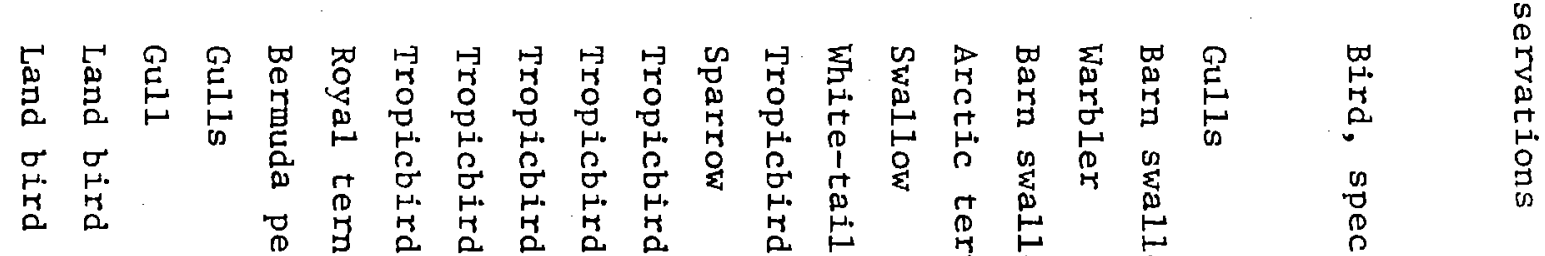

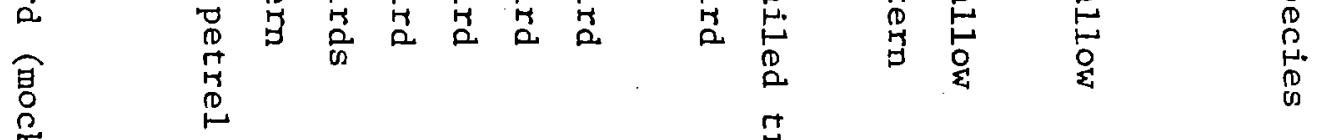

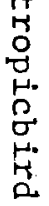

若

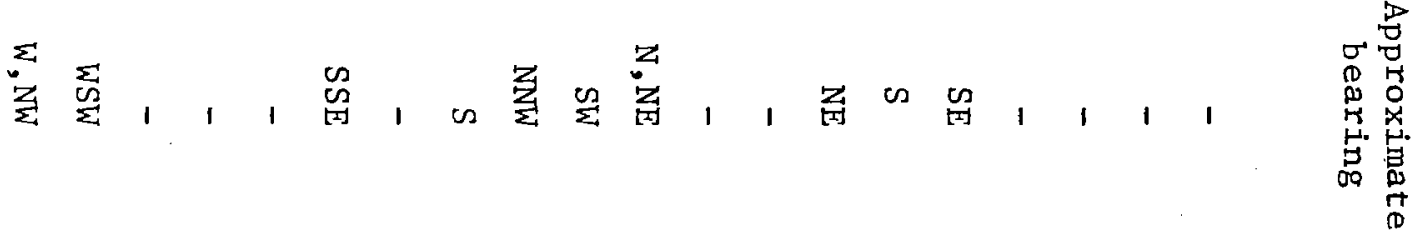


Hydro-E1ectric Generation Aboard Westward

Armond J. T'omassett1

\section{ABSTRACT}

This project was a study of the feasibility of using a hydrogenerating system aboard Westward. This was done by designing, building, and testing a small scale hydro-generator. The completed model used a flexible stainless steel cable to tow a propeller mounted on a two meter shaft. The propeller on its shaft turned the cable which turned a 24-volt DC generator attached to the transom of the vessel. While similar to commercial models, it had several design changes, including a propeller designed to give optimum revolutions per minute at about six knots (see Figure 12).

Tests revealed that although the spinner system and its design changes were successful, the energy contribution to the vessel was relatively sma11. At a ship's speed of flve knots, the generator turned at 1000 RPM, generating about 10 volts of electricity at about two amps. This compared favorably with a comparable commercial style propeller tested, which required six knots to generate 1000 RPM.

Studies of the Westward's speed during the cruise indicated that the ship spent an average of only three usable hours per day moving at an effective speed for the hydrogenerator. A design more suitable for the Westward would probably use a fixed shaft through the hull, eliminating the need to set and retract the spinner. 
SPRUCE HYDROGENERATOR
PROPELLER

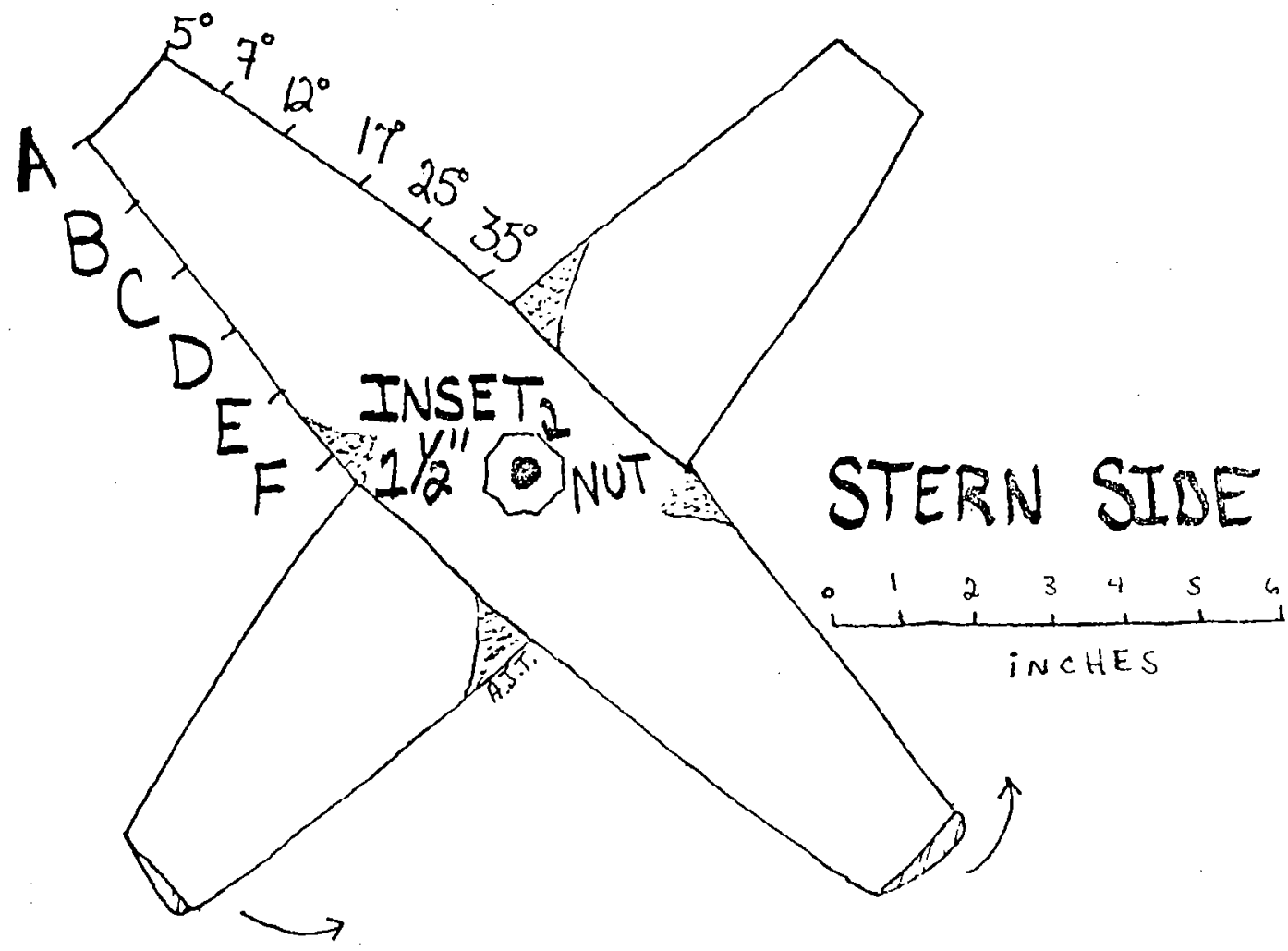

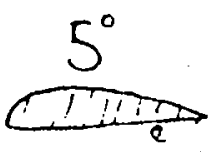

A

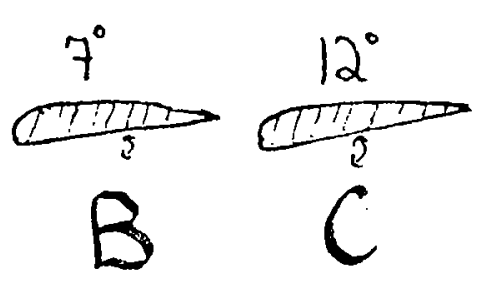

CROSS

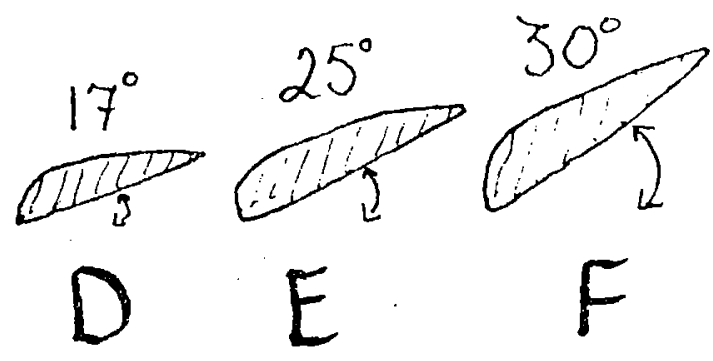

- Pitch

SECTION

Figure 12. Design of a spruce propeller tested with a hydrogenerator system aboard the $R / V$ Westward. 
A Redesign of the Westward Galley

Laura Fitch

\section{ABSTRACT}

An analysis was made of the components and effects of the working conditions within the galley of the $R / V$ Westward. By utilizing the scientific approach to problem solving of the School of Environmental Design, two physical form solutions were generated. The first solution optimizes space and functions without consideration of port time and expenses needed for extensive alterations, and involves many structural changes between the head, annex, and galley areas (see Figure 13). The The second solution is more modest, and attempts to optimize the present available galley space, but therefore does not solve every major, existing problem (see Figure 14). Although the second solution might improve the comfort of the workers and the sanitation of operations, the major problem of movement within and about the galley cannot be solved adequately without major structural changes. 
FINAL SOLUTION A

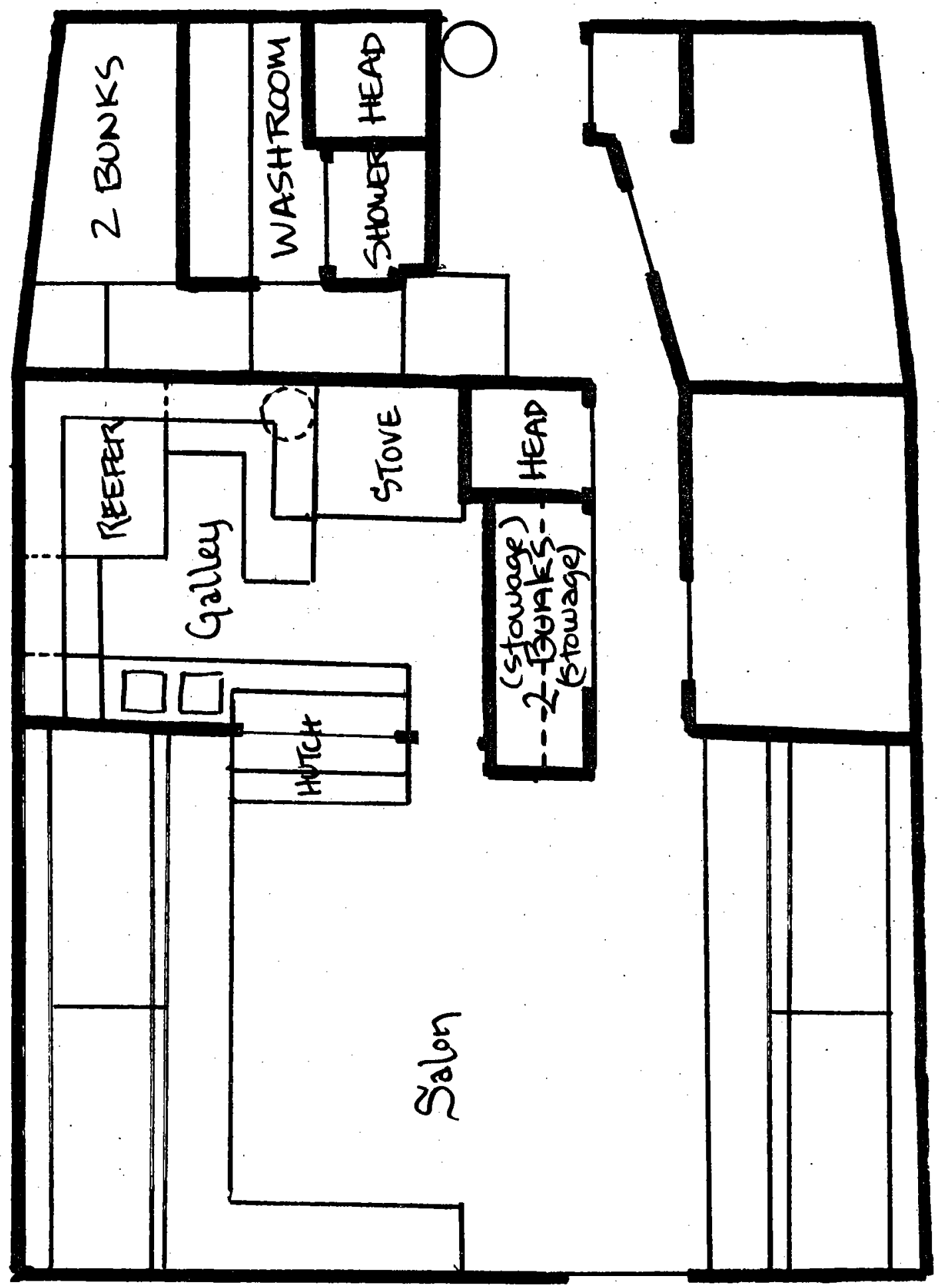

Figure 13 . 
Final Design $B$ :

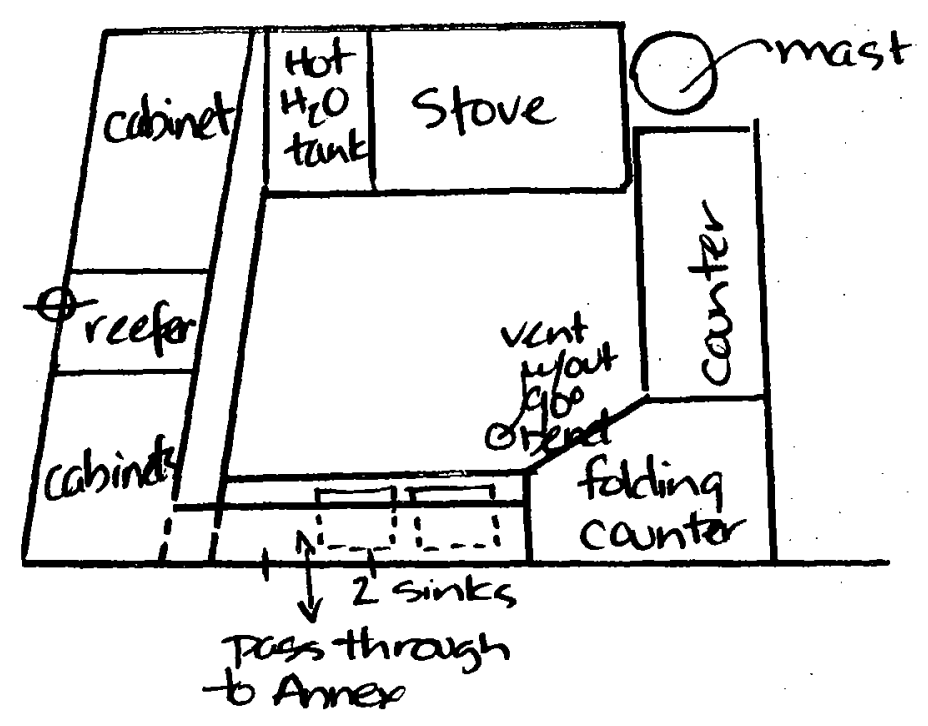

Previous Design:

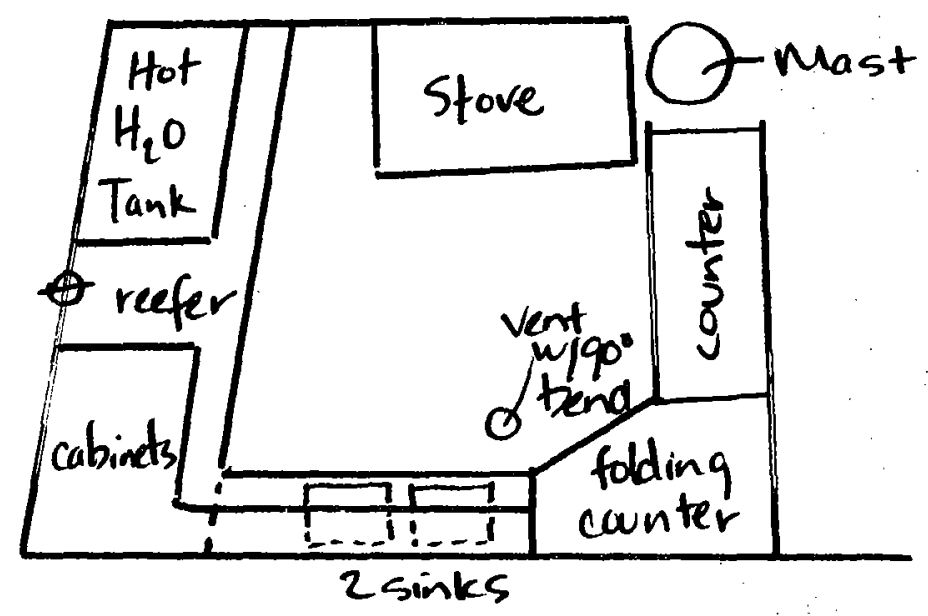

Figure 14 . 
Taxonomic list of the collections by the $R / V$ Westward for the Division of Invertebrate Zoology of the Peabody Museum of Natural History, Yale University.

Leg 2 of cruise $W-52$ of the R/V Westward

20 .June, 1980 to 4 Ju1y, 1980

Phylum Number of specimens

Porifera

Class Demospongia

Cnidaria

Class Hydrozoa

Class Scyphozoa

4

36

Ctenophora

Class Tentaculata

6 probably Pleurobrachia

Nemert inea

Subclass Hoplonemertini

1

Chaetognatha

Annelida

Class Polychaeta

5 tubiculous Errantia

Mo11usca

Class Scaphopoda

Class Bivalvia

Class Gastropoda

51 Dentalium, 4 Cadulus

1

31 naticid, probably Lunatia prosobranchia:mesonastropods

1 colid nudibranch

1 pteropod, probably Clione

Echinodermata

Class Echinoidea:Order Clypeastroida

Arthropoda

Class Crustacea:Order Isopoda

2 valvifera

Order Decapoda

18

Chordata: Subphylum Urochordata

Class Thalliacea

$\operatorname{total} \frac{1}{120}$ (25 lots)

The majority of specimens were taken by plankton net, some were taken by dip net, and one was taken by a baited line.

(The naticid was taken on Carol Sohon's jig line baited with haddock guts) 


\section{APPENDIX A \\ Westward's Itinerary - W-52}

ARRIVE

$\begin{array}{llrlr}\text { Leg } 1 & \text { Boston, MA } & 4 \text { June } 80 & \text { St. Georges, Bermuda } & 20 \text { June } 80 \\ \text { Leg } 2 & \text { St. Georges, Bermuda } & 22 \text { June } 80 & \text { Lunenburg, N.S., Canada } & 4 \text { July } 80 \\ \text { Leg } 30 & \text { Lunenburg, N.S. } & 6 \text { July } 80 & \text { Bath, ME } & 12 \text { July } 80 \\ & \text { Bath, ME } & 13 \text { July } 80 & \text { Woods Hole, MA } & 16 \text { July } 80\end{array}$


APPENDIX B

Ship's Complement

$\underline{\text { Nautical Staff }}$

Richard W. Farre11, Jr., B.A., Ocean Operator

Master

Paul B. DeOrsay, B.A., 100 ton Operator

Chief Mate

Charles "Ch1p" Swicker, B.A.

Second Mate

Terry $\Lambda$. Hayward, ITT, B.A., J.D.

Third Mate

Steven M. Miller, A.S., Chief Engineer, USCG Lic.

Chief Engineer

Mary O'Brien, RN

Steward

Scientific Staff

Hermann Gucinski, M.S.T.A.

Chief Scientist

Rob Moir, M.S.T.

Scientist

Rindy Ostermann, B.A.

Scientist

\section{Vistting Scholars}

Adam Joe, B.A., Marine Science (Leg 1)

Ron Eng, M.S., Peabody Museum of Natural History (Leg 2)

Carol Reinisch, Ph.D., Harvard University (Leg 2)

William M. Fowler, Ph.D., Northeastern University (Leg 3)

Stuart Frank, M.A., Mystic Seaport Museum (Leg 3)

\section{Students}

Paul D. Berkner, St. Francis College, Marine Biology, Junior

Linda A. Carlson, Carroll College, Biology, Junior

Phyllis T. Duncke1, Cornell University, Biology, Senior

Mary Kyle Dyer, Colby-Sawyer College, American Studies, Junior

Marina S. Finch, Dartmouth College, American Maritime Studies, B.A.

Laura E. Fitch, University of Colorado, Environmental Design, Freshman

Shawn P. Gallagher, SUNY/Fredonia, B.S. and Cornell University, Plant Science, Senior 
Leah H. George, Kenyon College, Biology, Sophomore

Ruth A. Gorski, Brown Universtty, Geology, B.S.

Patricia A. Hansen, University of Wisconsin at Green Bay, Science and Environmental Change, Junior

Laura M. Herr, Unfversity of Delaware, Biology, Junior

Holly F. Huddleston, DePauw University, Zoology, Junior

Amy R. Know1ton, Boston University, Archaeology, Sophomore

Braddock K. Linsley, St. Lawrence University, Geology, Sophomore

Kevin A. McGrath, Stonehill College, Criminal Justice, Senior

Alice L. Rand, Cornell University, General Agriculture, Senior

Frank D. Schuh, University of Wisconsin at Green Bay, Biology, Junior

Michael D. Schulze, Western Michigan University, Geology, Junior

Gwen1lian B. Scott (Gwen), Hobart and William Smith Colleges, Sophomore

Carol F. Sohon, University of Rhode Island, Fisheries, Junior.

Karen A. Tierney, Southeastern Massachusetts University, Marine Biology, Senior

Armond J. Tomassetti (Jeff), Boston University, International Relations, Sophomore

Andrea Westinghouse, Colgate University, Geology, B.A. 


$$
\begin{gathered}
\text { APPENDIX C } \\
\text { "Creature Features" W-52 } \\
\text { Demonstration Organisms }
\end{gathered}
$$

Division Phaeophyta

$$
\text { Sargassum fluitans }
$$

Division Cyanophyta

$$
\text { Trichodesmium sp. }
$$

Division Chrysophyta

$$
\text { Ceratium sp. }
$$

Phylum Protozoa

Class Foraminifera

Homotrema rubrum

Phylum Cten ophora

Beroe sp.

P1eurobranchia sp.

Phylum Mollus a

Class Gastropoda

Scyllae pelagica

Phylum Arthropoda

Class Insecta

Class Crustacea Halobates micans

Phronima sedentaria

Copepods, calanoid type

Acanthephyra pelagica

Phylum Echinodermata

Class Enchinoidea

Enchinometra 1ucunter

Phylum Chaetognatha

Sagitta sp.

Phylum Cnid arian

Class Anthozia

Class Hydrozoa

Porpita porpita

Physalia physalia

Class Scyphozoa

Pelagica noctiluca 
Phylum Chordata

Subphylum Vertebrata

Class Osteichthys

Class Aves
Hippocampus hudsonius

Myctophum punctatum

Leptocephalus eel larvae

Oceanites oceanicus 
TECHNIQUES

Oxygen Measurement

Salinity Measurement

Nansen Casts

Reversing Thermometers

Collecting and Preserving Zooplankton

Controls in Scientific Analysis

PHYSICAL/CHEMICAL

Surface Tension and Seawater

Co1d Core Eddy Transects

Temperature Structure of the Upper Ocean

Chlorophyll and the Surface Microlayer

BIOLOGICAL

Pelagic Birds

Ecology and Geology of Bermuda

Trichoclesmium sp.

Structure and Function in Fishes

Immunology and the Marine Environment

OTHER

The Mesopelagic Duck and Related Species
Gucinski

Gucinski

Moir

Gucinski

Ostermann

Reinisch

Gucinski

Moir, Ostermann

Ostermann, Moir

Gucinski

Moir

Moir, Westinghouse

Ostermann

Ostermann

Reinisch

Ostermann, Moir 
APPENDIX E

Summary Log of Stations Done on Cruise W-52

\begin{tabular}{|c|c|c|c|c|c|}
\hline Station No. & Date & Time & Lat. (N) & Long. (W) & Operation \\
\hline W52-A & $5 / \mathrm{VI}$ & 0300 & $42^{\circ} 12^{\prime}$ & $70^{\circ} 15^{\prime}$ & Phytoplankton tow \\
\hline W52-1 & $5 / \mathrm{VI}$ & 1735 & $41^{\circ} 39^{\prime}$ & $69^{\circ} 01^{\prime}$ & Gravity core \\
\hline W52-2 & $6 / \mathrm{VI}$ & 0535 & $41^{\circ} 05^{\prime}$ & $68^{\circ} 28^{\prime}$ & $\begin{array}{l}\text { Phytoplankton tow } \\
\text { Gravity core }\end{array}$ \\
\hline W52-3 & $6 / V I$ & 2025 & $40^{\circ} 30^{\prime}$ & $68^{\circ} 09^{\prime}$ & Gravity cores (2) \\
\hline W52-4 & $\cdot 7 / V I$ & 0600 & $40^{\circ} 16^{\prime}$ & $67^{\circ} 58^{\prime}$ & $\begin{array}{l}\text { Phytoplankton tow } \\
\text { Gravity core }\end{array}$ \\
\hline W52-5 & $7 / \mathrm{VI}$ & 0945 & $40^{\circ} 15^{\prime}$ & $67^{\circ} 54^{\prime}$ & $\begin{array}{l}\text { Phytoplankton tow } \\
\text { Gravity core }\end{array}$ \\
\hline W52-6 & $9 / \mathrm{VI}$ & 1450 & $39^{\circ} 21^{\prime}$ & $66^{\circ} 39^{\prime}$ & Neuston tow \\
\hline W52-7 & $10 / \mathrm{VI}$ & 0045 & $39^{\circ} 02^{\prime}$ & $65^{\circ} 45^{\prime}$ & Neuston tow \\
\hline W52-8 & $10 / \mathrm{VI}$ & 1215 & $38^{\circ} 47^{\prime}$ & $66^{\circ} 18^{\prime}$ & Neuston tow \\
\hline W52-9 & $11 / \mathrm{VI}$ & 0000 & $38^{\circ} 21^{\prime}$ & $66^{\circ} 23^{\prime}$ & Neuston tow \\
\hline W52-10 & $11 / \mathrm{VI}$ & 1255 & $38^{\circ} 08^{\prime}$ & $66^{\circ} 45^{\prime}$ & Neuston tow \\
\hline W52-11 & $11 / \mathrm{VI}$ & 1720 & $38^{\circ} 40^{\prime}$ & $66^{\circ} 37^{\prime}$ & $\begin{array}{l}\text { Hydrocast } \\
\text { Meter net tow }\end{array}$ \\
\hline W52-12 & $12 / \mathrm{VI}$ & 0010 & $38^{\circ} 02^{\prime}$ & $66^{\circ} 39^{\prime}$ & Neuston tow \\
\hline W52-13 & $12 / \mathrm{VI}$ & 1215 & $37^{\circ} 23^{\prime}$ & $66^{\circ} 53^{\prime}$ & $\begin{array}{l}\text { Neuston tow } \\
\text { Hydrocast }\end{array}$ \\
\hline W52-14 & $13 / \mathrm{VI}$ & 1155 & $36^{\circ} 35^{\prime}$ & $66^{\circ} 48^{\prime}$ & Neuston tow \\
\hline W52-15 & $14 / \mathrm{VI}$ & 1315 & $36^{\circ} 18^{\prime}$ & $67^{\circ} 55^{\prime}$ & Phytoplankton tow \\
\hline \multirow[t]{4}{*}{ W52-16 } & $15 / \mathrm{VI}$ & 1300 & $35^{\circ} 39^{\prime}$ & $66^{\circ} 09^{\prime}$ & $\begin{array}{l}\text { Meter net tow } \\
\text { Neuston tow } \\
\text { Phytoplankton tow } \\
\text { Hydrocast } \\
\text { Irradiometer }\end{array}$ \\
\hline & & 1900 & $35^{\circ} 48^{\prime}$ & $66^{\circ} 04^{\prime}$ & $\begin{array}{l}\text { Meter net tow } \\
\text { Hydrocast }\end{array}$ \\
\hline & $16 / \mathrm{VI}$ & 0000 & & & Meter nét tow \\
\hline & & 0630 & & & $\begin{array}{l}\text { Meter net tow } \\
\text { Irradiometer }\end{array}$ \\
\hline W52-17 & $17 / V I$ & 1215 & $34^{\circ} 58^{\prime}$ & $65^{\circ} 08^{\prime}$ & Neuston tow \\
\hline W52-18 & $18 / \mathrm{VI}$ & 0015 & $34^{\circ} 29^{\prime}$ & $64^{\circ} 38^{\prime}$ & Neuston tow \\
\hline W52-19 & $19 / \mathrm{VI}$ & 1220 & $32^{\circ} 52^{\prime}$ & $64^{\circ} 33^{\prime}$ & Neuston tow \\
\hline
\end{tabular}


APPENDIX E (continued)

\begin{tabular}{|c|c|c|c|c|c|}
\hline W52-20 & $20 / V I$ & 0025 & $32^{\circ} 26^{\prime}$ & $64^{\circ} 14^{\prime}$ & Neuston tow \\
\hline W52-21 & $23 / V I$ & 1230 & $33^{\circ} 08^{\prime}$ & $64^{\circ} 17^{\prime \prime}$ & Neuston tow \\
\hline W52-22 & $24 / V I$ & 0000 & $33^{\circ} 19^{\prime}$ & $66^{\circ} 01^{\prime}$ & $\begin{array}{l}\text { Meter net tow } \\
\text { Hydrocast }\end{array}$ \\
\hline W52-23 & $24 / \mathrm{VI}$ & 1227 & $33^{\circ} 24^{\prime}$ & $65^{\circ} 24^{\prime}$ & Neuston tow \\
\hline W52-24 & $25 / V I$ & 0000 & $33^{\circ} 35^{\prime}$ & $65^{\circ} 46^{\prime}$ & $\begin{array}{l}\text { Neuston tow } \\
\text { Meter net tow }\end{array}$ \\
\hline W52-25 & $25 / V I$ & 2300 & $34^{\circ} 23^{\prime}$ & $66^{\circ} 11^{\prime}$ & $\begin{array}{l}\text { Neuston tow } \\
\text { Meter net tow }\end{array}$ \\
\hline W52-26 & $29 / V I$ & 1345 & $41^{\circ} 18^{\prime}$ & $66^{\circ} 13^{\prime}$ & Meter net tow \\
\hline W52-B & $29 / \mathrm{VI}$ & 2010 & $41^{\circ} 20^{\prime}$ & $66^{\circ} 12^{\prime}$ & Longline \\
\hline W52-27 & $30 / \mathrm{VI}$ & 0834 & $41^{\circ} 27^{\prime}$ & $65^{\circ} 41^{\prime}$ & $\begin{array}{l}\text { Meter net tow } \\
\text { Hydrocast } \\
\text { Irradiometer }\end{array}$ \\
\hline W52-28 & 1/VII & 0100 & $42^{\circ} 02^{\prime}$ & $66^{\circ} 23^{\prime}$ & $\begin{array}{l}\text { Otter trawl } \\
\text { Phytoplankton tow } \\
\text { Hydrocast } \\
\text { Bottom grab }\end{array}$ \\
\hline W52-29. & 1/VII & 1220 & $42^{\circ} 08^{\prime}$ & $66^{\circ} 57^{\prime}$ & $\begin{array}{l}\text { Hydrocast } \\
\text { Bottom grab }\end{array}$ \\
\hline W52-30 & 2/VII & 0445 & $42^{\circ} 05^{\prime}$ & $66^{\circ} 50^{\prime}$ & Vertical tow \\
\hline W52-31 & $2 / V I I$ & 2145 & $42^{\circ} 27^{\prime}$ & $66^{\circ} 01^{\prime}$ & $\begin{array}{l}\text { Meter net tow } \\
\text { Phytoplankton tow }\end{array}$ \\
\hline W52-32 & 3/VII & 2025 & $44^{\circ} 39^{\prime}$ & $64^{\circ} 30^{\prime}$ & Phytoplankton tow \\
\hline W52-33 & $6 /$ VII & 2132 & $43^{\circ} 52^{\prime}$ & $64^{\circ} 21^{\prime}$ & Phytoplankton tow \\
\hline W52-34 & $7 / \mathrm{VII}$ & 0555 & $43^{\circ} 02^{\prime}$ & $66^{\circ} 30^{\prime}$ & Phytoplankton tow \\
\hline W52-35 & $8 /$ VII & 0130 & $42^{\circ} 12^{\prime}$ & $64^{\circ} 28^{\prime}$ & $\begin{array}{l}\text { Meter net tow } \\
\text { Phytoplankton tow }\end{array}$ \\
\hline W52-36 & 9/VII & 1850 & $42^{\circ} 11^{\prime}$ & $65^{\circ} 21^{\prime}$ & Gravity core \\
\hline W52-37 & 10/VII & 2030 & $43^{\circ} 06^{\prime}$ & $68^{\circ} 33^{\prime}$ & Longline \\
\hline
\end{tabular}


1. We boarded WESTWARD in the pouring rain Left for Boston, we were so glad we came Unt11 we hit our first force nine gale And went directly to the leeward rail.

Heave and hauling on the wrong sheet Then make it fast to the wrong cleat The captain ordered me to steer full and bye Can't stay on course no matter how hard I try.

\section{CHORUS}

And then it's WESTWARD in the moonlight Teak beach, drinking Hi-C all night Thought my four thousand dollar sun tan was near Until we tied up at the Lunenburg pier.

Wa la every watch standers dream Where we can go and eat rum raisin ice cream We' 11 buy our souvenirs and then hit the bar Where the captain and staff already are.

2. Woke up this morning we were hove to Got off watch and we were hove to Went to class and learned how to heave to 52 became the hove to crew.

Wind finally came up, it was right on our bow How the hell can we reach Bermuda now This was supposed to be a downwind satl And then we hit another force nine gale.

\section{$\underline{\text { CHORUS }}$}

3. Get out your harness and your brown paper bag This cruise is really getting to be a drag Until the sun came pouring through And we dove into the Sargasso blue.

We hit St. Georges in the pouring rain The customs officer well he never came What ever happened to the Bermuda high? We keep on looking for a little blue sky.

\section{CHORUS}


4. We donned our helmets and we rented mopeds Wrong side, there's a car straight ahead Collected urchins, got all battered and bruised Went to the Carriage House and got really juiced.

We left Bermuda in the pouring rain I'11 tell you these BT's are really a pain To do a tow we use the hydrowinch With Hermann in the head it's really a cinch.

\section{CHORUS}

5. And now you're JWO and you can't even see Your bow watch tells you he smells a pine tree Just when you think you've things under control now Chip says ten targets off the starboard bow.

We anchored WESTWARD with the Phleger core If you want better, go out on the KNORR Our bottom grabs didn't get much but you know We sampled bottom with our meter net tows.

\section{CHORUS}

6. We took a pilot up the Kennebeck

Al1 hands turned out to scrub the deck

We used our Brasso, Ospho, red lead and white Oh but WESTWARD was a beautiful sight.

We motored WESTWARD down Buzzard's Bay The sclence practical was under way Weighed anchor in the morning and don't you know The wind came from ahead and started to blow:

Oh God, if I ever get home I swear that never on the seas will I roam I'11 think of WESTWARD and I'11 smile of good cheer For all the friends and good times we had here. 